\title{
TESTS OF CELLULAR SHEET-STEEL FLOORING
}

\author{
By J. M. Frankland ${ }^{1}$ and H. L. Whittemore
}

\section{ABSTRACT}

The strength and elastic properties of a new type of cellular steel structural floor were determined. The floor panels were made from 12, 14, 16, and 18 United States standard gage special corrugated sheets which were spot-welded together into panels 2 feet wide and about 11 feet long. The weights ranged from 8 to $16 \mathrm{lbs} . / \mathrm{ft}^{2}$ The specimens were tested under transverse loading at the quarter points, measurements of strain and deflection being taken at mid-span. It was found that the Euler-Bernoulli theory commonly used in designing beams could be applied satisfactorily to predict the elastic behavior. On 10-foot spans, the floor panels behaved elastically under loads equal to or greater than those which would produce a deflection of one-three hundred and sixtieth of the span. The maximum load was in all cases considerably higher than the limit of elasticity of the panels and assured a considerable margin of safety against overloading. The sections were very stable under the concentrated loads and reactions.

The tensile properties and Young's modulus of elasticity were determined for the sheet steel used in the floor specimens, as was also the shearing strength of the spot welds.

\section{CONTENTS}

I. Introduction

1. General

2. The cellular floor

II. Acknowledgments

III. Description of the specimens 133

IV. Tensile tests of the material 136

1. Methods of tests

2. Results

V. Shearing strength of the welds 141

1. General.

2. Methods of testing 141

3. Results

VI. Method of testing floor panels 144

1. Information desired. 144

2. Test procedure

VII. Results of the panel tests 147

VIII. Discussion of the test results of the panels

1. Specimens of types A and B

(a) Elastic behavior.

(b) Neutral axis

(c) Welds . .

(d) Cell heights at the supports

(e) Failure of the panels..... 159

2. Specimens of type C. 161

IX. Conclusions

\section{INTRODUCTION}

\section{GENERAL}

Modern practice in building construction often provides a structural steel frame on which is carried the walls and floors. The walls provide protection against weather, the floors carry the actual weight of the occupancy. The floor beams inclose areas usually 15 to 25 feet square

1 Research Associate representing the American Institute of Steel Construction, New Y ork, N. Y. 
which are filled in with a variety of constructions. A concrete slab is often used, with or without the use of steel or concrete secondary beams. Tile arches with reinforcement are sometimes used, or else a combination of concrete and tile construction. For all these constructions the weight of the floor is usually greater than the live load it is designed to carry, often considerably so. The cost of the steel frame and the foundations is therefore greatly influenced by the weight of the floor construction. Consequently many engineers and manufacturers are endeavoring to design and produce a load-carrying member for a floor which will be lighter and more convenient than these already in use. It would be desirable to have a lightweight unit which would lend itself to the possibilities of mass production and at the same time could be economically shipped to the site and laid rapidly in place, affording workmen at once a working floor and a place for storing materials. At present the greatest possibilities seem to lie in metal construction.

The advantages to be gained by the use of a lightweight floor in buildings are apparent. For bridges also such a floor would be desirable. As W. H. Thorpe has shown ${ }^{2}$ for a bridge of given general type, the load-carrying capacity per pound of structure depends primarily on the span and the ratio of live load to weight of the floor system. For long-span bridges and tall buildings the weight of floors has a cumulative effect. If the dead loads due to the floor system can be reduced, it will result in a much greater reduction in the total weight of the structure, making possible very appreciable economies in material in these two fields.

\section{THE CELLULAR FLOOR}

Sheet steel, which is now one of the leading products of the steel industry, can be readily formed into corrugated sheets in thicknesses up to 7 gage. $^{3}$ The load-carrying properties of these sheets may be materially increased by adding another sheet, flat or corrugated, to form a cellular construction. The two sheets may be either riveted or welded together, the latter process being particularly adapted to large-scale production. A panel made in such a way would be characterized by longitudinal stiffening cells. Such a construction lends itself to an economic use of the material, as much of it as possible being stressed to the allowable working stress, resulting in a beam of high strength in proportion to its weight.

Panels of this sort seem well suited for the construction of floors. They could be shop fabricated and shipped to the construction site where they would be available for rapid placing to form a continuous working floor as soon as the beams were erected to carry them. The cellular structure provides also a system of ducts which appears to offer possibilities of considerable economy in running plumbing, heating and ventilating, electrical, and compressed-air lines.

Experiments by a manufacturer resulted in the development of two types of sheet steel cellular floor panels which appeared to have sufficient strength. These are shown in Figures 1 and 2 . The panels are 2 feet wide and any desired length up to 12 feet. The sheets are joined by spot welds.

2 Steel Bridge Weights, Engineering, vol. 120, p. 534, 1925.

30.188 inch. United States standard gage for sheet, plate, iron, and steel. 
B. S. Journal of Research, RP463

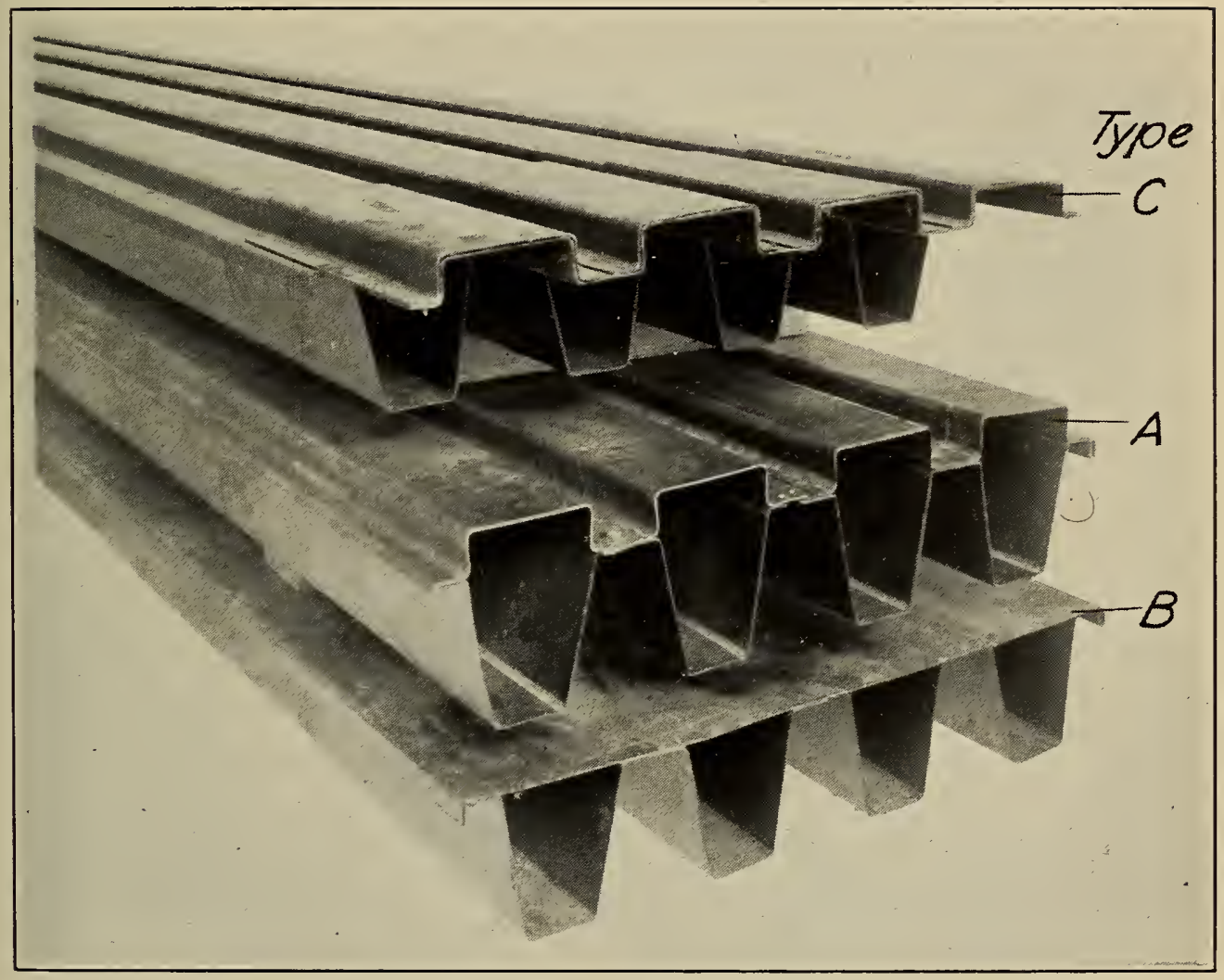

Figure 1.-End view of floor types $A, B$, and $C$ 
The manufacturer's experiments indicated that panels weighing in the neighborhood of $10 \mathrm{lbs} . / \mathrm{ft}^{2}{ }^{2}$ would be adequate for most floor loads. The dead load of such a floor would consequently be due for the major part to the fireprooing and floor finish. It has been estimated that with this construction there can be saved about one-haif of the dead load due to the floor compared to constructions now in common use, this saving varying somewhat with the live load and being subject to modification according to local requirements for fireproofing.

Before putting such a new construction into service, it was considered advisable to make a thorough study of the panels under load

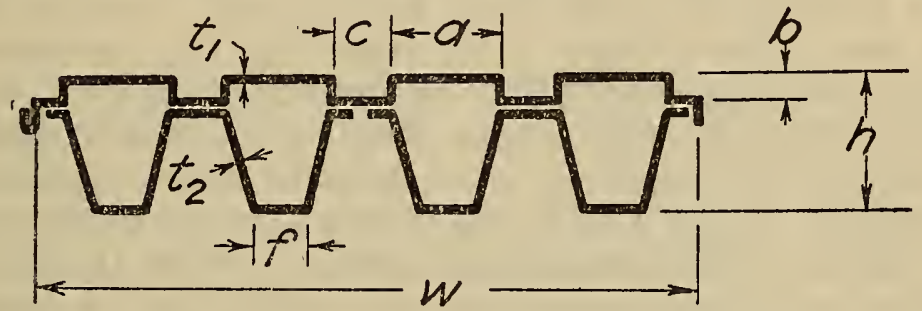

Types A \& C

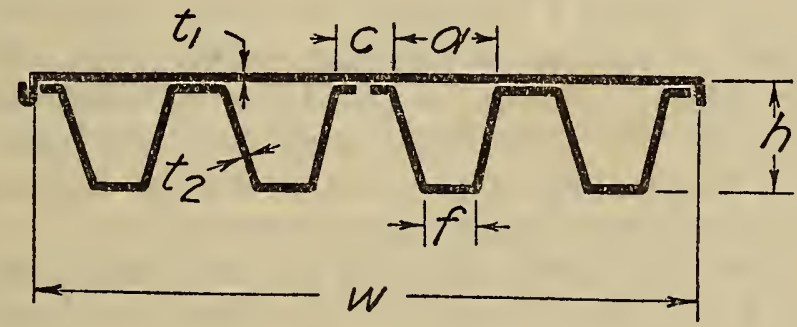

Type B

Figure 2.-Sections of floor panels

The average numerical values of the dimensions indicated by letters are given in Table 2 for each specimen.

to see how closely their performance could be predicted by conventional engineering theory.

\section{ACKNOWLEDGMENTS}

The American Institute of Steel Construction sponsored the investigation, which was made under the research associate plan at the Bureau of Standards. The specimens were designed and manufactured by the H. H. Robertson Co., Pittsburgh, Pa. Dr. A. H. Stang and L. R. Sweetman, of the bureau staff, assisted in the analysis of the problem and in making the tests.

\section{DESCRIPTION OF THE SPECIMENS}

The specimens were of three types, sections of which are shown in Figure 2. Types $\mathrm{A}$ and $\mathrm{C}$ consisted of two corrugated sheets and type $\mathrm{B}$ of one corrugated sheet and a flat sheet, the bottom sheets being of the same dimensions for each type. The corrugated upper surface was designed to bind with a surface slab of concrete or similar 
material. The troughs in the top sheet also offer certain advantages in laying pipes and ducts. If a concrete slab is not used, the troughs can be covered with sheet-metal channels to give a smooth upper panel surface. Cork, rubber tile, or linoleum may be laid directly on the flat top sheet of the panels of type B. Different strengths were obtained by varying the thicknesses of top and bottom sheets. Type $\mathrm{C}$ differed from type $\mathrm{A}$ in having the lower corrugations cut away for a distance of 6 inches from each end, the projecting portion of the top sheeting being reinforced in the manner shown in Figure 1. There was no reinforcement of the welds at the ends of the bottom corrugations. The object of this design was to enable this type of panel to be framed into the floor beams with the top sheet lying directly on the upper flange, thus reducing the distance from the finished floor surface to the ceiling immediately below.

Where the top and bottom sheets of a panel were in contact between the cells, they were joined by two rows of three-eighths-inch spot welds, the welds being about $1 \frac{1 / 2}{2}$ inches apart in each row. The horizontal portion of the assembled section where these welds occur will be spoken of subsequently as the web. In all specimens the bottom sheet was made in two parts separated down the center web. In all the specimens numbered X through XXIV the top sheet was in one piece, this representing the latest manufacturing method. The top sheets of specimens I through IX were made in two pieces with the separation occurring down the center web, this type of construction being clearly shown in the type A panel of Figure 1. In all type $B$ specimens the top sheets were in one piece.

The top sheet of the panels was bent down on either side for a lateral connection to adjacent panels when erected.

The specimens were uncoated showing the mill scale on the sheets except for numbers I, VI, X, XI, and XII, which had been given one coat of paint, inside the cells as well as on the outside surface.

All specimens were 24 inches wide and either 10 or 11 feet long. The cells were spaced 6 inches on centers and in types $A$ and $C$ were $5 \frac{5}{8}$ inches deep, in type $\mathrm{B}, 4 \frac{3 \%}{8}$ inches deep.

A specimen will be described hereafter by its type letter, followed by the gage numbers of the top and bottom sheets, respectively. The gage used is the United States standard gage for sheet, plate, iron, and steel. The nominal thicknesses in inches, together with the maximum and minimum values observed may be found in Table 1. The relative variation of thickness in any one sheet was much less. When the bottom corrugations were made from material lighter than 16 gage, preliminary experiments by the manufacturer had shown that the cell bottoms are liable to crumple over the support. To avoid this the cell bottoms of the A16-18 specimens tested were reinforced at the ends by pieces of 18 gage sheet of the same shape and 6 inches long which were welded to the webs, giving in effect a double cell bottom over the supports.

The first group of specimens, numbered I to XII, were manufactured on a power cornice brake, the dimensions being obtained by hand setting of the sheet in the machine. These will be referred to later as "hand-set specimens." They were characterized by a certain irregularity in the dimensions and a lack of evenness in the 
load-bearing surfaces. Specimens XII to XXIV were formed in the same machine over dies which gave much more uniform dimensions.

TABLE 1.-Thickness of sheets

\begin{tabular}{|c|c|c|c|}
\hline \multirow{2}{*}{\begin{tabular}{c|c} 
Gage \\
No.
\end{tabular}} & $\begin{array}{c}\text { Nominal } \\
\text { thickness }\end{array}$ & \multicolumn{2}{|c|}{ Actual Thickness } \\
\cline { 3 - 4 } & & (Minimum) & (Maximum) \\
\hline & & & \\
12 & Inch & Inch & Inch \\
14 & 0.097 & 0.114 \\
16 & .077 & .069 & .083 \\
18 & .061 & .056 & .066 \\
& & .044 & .051 \\
\hline
\end{tabular}

The sheets were joined in all cases by resistance spot welding with three-eighths inch diameter welds. In the form of spot welding used, projection welding, small projections are formed on one of the sheets at the places where the welds are to be made. A hand-operated machine making one weld at a time and with the current controlled by a time switch was used on the first 12 specimens. The remaining specimens were welded on a multiple machine with full automatic control. Specimens XV, XXII, XXIII, and XXIV were welded on the automatic machine after its operation had been improved.

The dimensions of each cell and web were taken at both ends of a specimen and the results averaged to obtain data from which the moment of inertia and neutral axis location could be calculated. The measurements were taken to the nearest sixteenth of an inch, and the averaged results expressed to the nearest hundredth. Average dimensions and descriptions of the specimens are given in Table 2. Since the deviations in the dimensions of the most irregular panels did not produce differences of more than 2 per cent in the moments of inertia calculated cell by cell and from the averaged dimensions, it was not felt worth while to list the dimensions of the particular parts.

TABLE 2.-Description and dimensions of floor specimens

[The dimensions designated by letters are shown in fig. 2]

\begin{tabular}{|c|c|c|c|c|c|c|c|c|c|c|c|}
\hline Panel & Tуре & $a$ & $b$ & $c$ & $f$ & $h$ & $w$ & $t_{1}$ & $t_{2}$ & Length & $\begin{array}{l}\text { Nominal } \\
\text { weight }\end{array}$ \\
\hline 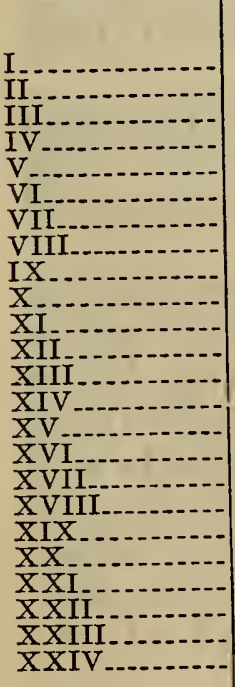 & $\begin{array}{l}\text { A14-16 } \\
\text { A14-16 } \\
\text { A14-16 } \\
\text { A16-18 } \\
\text { A16-18 } \\
\text { A16-18 } \\
\text { C14-16 } \\
\text { C14-16 } \\
\text { C14-16 } \\
\text { B16-16 } \\
\text { B16-16 } \\
\text { B16-16 } \\
\text { A14-16 } \\
\text { A16-18 } \\
\text { B16-16 } \\
\text { A14-14 } \\
\text { A14-14 } \\
\text { A14-14 } \\
\text { A12-12 } \\
\text { A12-12 } \\
\text { A12-12 } \\
\text { A14-16 } \\
\text { A14-16 } \\
\text { A14-16 }\end{array}$ & \begin{tabular}{|c|} 
Inches \\
3.86 \\
3.91 \\
3.90 \\
3.89 \\
3.88 \\
3.90 \\
3.88 \\
3.84 \\
3.88 \\
3.76 \\
3.80 \\
3.72 \\
3.94 \\
3.81 \\
3.82 \\
3.88 \\
3.91 \\
3.91 \\
3.91 \\
3.92 \\
3.88 \\
3.92 \\
3.88 \\
3.87
\end{tabular} & \begin{tabular}{|c|} 
Inches \\
1.29 \\
1.29 \\
1.32 \\
1.29 \\
1.31 \\
1.28 \\
1.29 \\
1.29 \\
1.31 \\
0 \\
0 \\
0 \\
1.26 \\
1.23 \\
0 \\
1.24 \\
1.27 \\
1.25 \\
1.24 \\
1.25 \\
1.25 \\
1.25 \\
1.24 \\
1.24
\end{tabular} & \begin{tabular}{|c|} 
Inches \\
2.04 \\
2.16 \\
2.07 \\
2.12 \\
2.15 \\
2.08 \\
2.14 \\
2.09 \\
2.10 \\
2.10 \\
2.07 \\
2.11 \\
2.05 \\
2.22 \\
2.12 \\
2.10 \\
2.10 \\
2.11 \\
2.15 \\
2.11 \\
2.11 \\
1.98 \\
2.00 \\
2.02
\end{tabular} & \begin{tabular}{|c|} 
Inches \\
2.09 \\
2.16 \\
2.13 \\
2.13 \\
2.12 \\
2.11 \\
2.18 \\
2.12 \\
2.16 \\
2.16 \\
2.12 \\
2.18 \\
2.06 \\
2.12 \\
2.20 \\
2.17 \\
2.15 \\
2.14 \\
2.32 \\
2.28 \\
2.27 \\
2.19 \\
2.12 \\
2.14
\end{tabular} & $\begin{array}{c}\text { Inches } \\
5.64 \\
5.65 \\
5.69 \\
5.64 \\
5.60 \\
5.66 \\
15.66 \\
15.66 \\
15.66 \\
4.35 \\
4.35 \\
4.37 \\
5.70 \\
5.64 \\
4.34 \\
5.71 \\
5.71 \\
5.70 \\
5.53 \\
5.57 \\
5.61 \\
5.64 \\
5.66 \\
5.66\end{array}$ & \begin{tabular}{|c|} 
Inches \\
24.78 \\
24.44 \\
24.31 \\
.----- \\
24.50 \\
24.44 \\
24.47 \\
24.50 \\
24.03 \\
24.22 \\
24.34 \\
24.13 \\
24.00 \\
24.38 \\
24.00 \\
24.50 \\
24.12 \\
24.12 \\
24.25 \\
24.00 \\
24.06 \\
23.88 \\
23.75 \\
23.81
\end{tabular} & $\begin{array}{c}\text { Inch } \\
0.074 \\
.075 \\
.074 \\
.060 \\
.060 \\
.061 \\
.075 \\
.075 \\
.079 \\
.057 \\
.060 \\
.060 \\
.076 \\
.063 \\
.061 \\
.077 \\
.077 \\
.077 \\
.108 \\
.113 \\
.108 \\
.080 \\
.080 \\
.079\end{array}$ & $\begin{array}{c}\text { Inch } \\
0.060 \\
.062 \\
.061 \\
.049 \\
.047 \\
.049 \\
.062 \\
.062 \\
.062 \\
.060 \\
.059 \\
.060 \\
.065 \\
.049 \\
.060 \\
.079 \\
.079 \\
.079 \\
.105 \\
.100 \\
.101 \\
.064 \\
.064 \\
.064\end{array}$ & $\begin{aligned} \text { Feet } \\
11 \\
11 \\
11 \\
11 \\
11 \\
11 \\
11 \\
11 \\
11 \\
11 \\
11 \\
11 \\
11 \\
11 \\
11 \\
11 \\
11 \\
11 \\
10 \\
10 \\
10 \\
11 \\
11 \\
11\end{aligned}$ & $\begin{array}{r}\text { Lbs./ft. } 1 \\
10.50 \\
10.50 \\
10.50 \\
8.50 \\
8.50 \\
8.50 \\
10.50 \\
10.50 \\
10.50 \\
8.25 \\
8.25 \\
8.25 \\
10.50 \\
8.50 \\
8.25 \\
11.50 \\
11.50 \\
11.50 \\
16.10 \\
16.10 \\
16.10 \\
10.50 \\
10.50 \\
10.50\end{array}$ \\
\hline
\end{tabular}

1 Calculated from average height of hand-set A14-16 specimens. 


\section{TENSILE TESTS OF THE MATERIAL}

\section{METHODS OF TEST}

The principal requirements of the usual commercial grades of black sheet steel are that the sheets should have a good surface and a high ductility to undergo various forming operations. They are not primarily intended for structural purposes. It was, therefore, desirable to investigate the structural properties, tensile strength, yield point and Young's modulus of elasticity of the material used in these floor panels.

A screw-power beam testing machine having a capacity of 20,000 pounds was used, the machine having two load ranges, one up to 2,000 pounds and the other up to 20,000 pounds. The former range was used for all specimens except the thickest (12 gage).

The specimen used is illustrated in Figure 3 and conforms to the requirements of the sheet tensile specimen recommended by the American Society for Testing Materials in their Tentative Methods

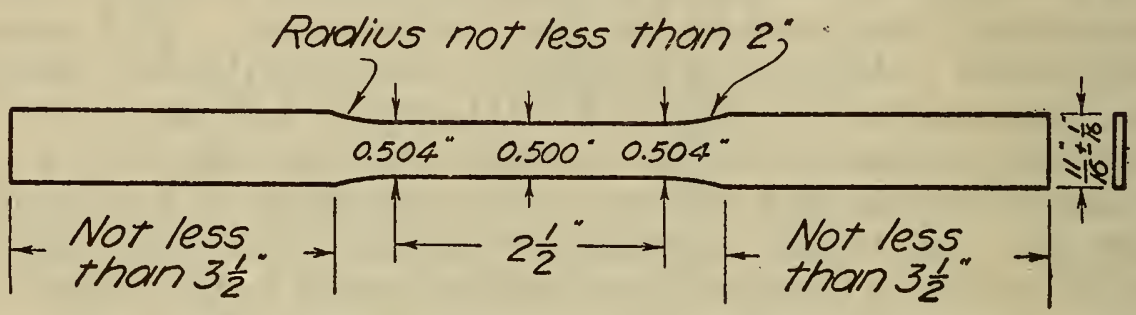

FiguRE 3.- Sheet tensile specimen

of Testing of Metallic Materials (Specification E8-27T, Proc., vol. 27, I, p. 1067). The gage length was 2 inches.

One hundred and twelve specimens were tested, 9 of 12 gage, 26 of 14 gage, 65 of 16 gage, and 12 of 18 gage. Stress-strain measurements were taken for 7 specimens of 14 gage, 6 of 16 gage, and 6 of 18 gage.

The tensile specimens were takken from coupons cut from the end of each sheet prior to forming. Tests were made both in the direction of rolling and transverse to this direction, these specimens being marked respectively $L$ and $T$. Ninety-three specimens were taken from panels I through XII and furnished information as to the properties of practically all the sheets entering into those panels. Nineteen specimens were taken from the remaining panels.

The stress-strain curves were obtained with a Ewing extensometer of 2-inch gage length mounted on the edges of the specimen. The load was maintained until any drift in extensometer readings appeared to cease and then the reading recorded.

For the remainder of the specimens only yield point, tensile strength, and elongation were determined. A slow machine speed was used as it was found that the values obtained were to a considerable degree dependent on the rate of extension. In some cases a preliminary load of roughly one-half the yield point was applied more rapidly and the rest of the test continued at the slower speed. The speeds adopted were 0.01 inch per minute until the load began to pick up after the yield point, and 0.09 inch per minute for the remainder of the test. These speeds were measured on the movable crosshead of the 
machine under no load. The yield points were determined by "drop of beam."

The cross section of the specimens was measured at the ends and at the center of the gage length. As will be seen from Figure 3 , the width of the specimen is less at the center to assure fracture near the middle of the gage length. The minimum of the three areas measured was used to compute yield point and tensile strength. The effective area for the determinations of Young's modulus was obtained by assuming that the area could be represented by a quadratic function of the position in the gage length. The effective area will then be given very closely by

$$
A=16\left(A_{1}+4 A_{0}+A_{2}\right)
$$

where $A_{0}$ is the area at the center and $A_{1}$ and $A_{2}$ the areas at the ends of the gage length. The formula will be recognized as Simpson's rule. The area so obtained is a closer approximation than would be obtained by the use of the average area.

From the stress-strain data were determined Young's modulus and the proportional limit, using the method of differences proposed by Dr. L. B. Tuckerman, of the Bureau of Standards. ${ }^{4}$ A trial modulus of elasticity of $30,000,000 \mathrm{lbs} . /$ in. $^{2}$ was assumed and differences between the observed strain and that calculated from the trial modulus were plotted in a difference curve. A straight line was drawn through the points on the difference curve in such a way as to include the most points within a range of one hundred-thousandth inch per inch strain on either side of the line. Slight irregularities at the lowest loads were disregarded. From the slopes of these lines were derived the actual moduli of the specimens. The proportional limit was taken as the stress at which the difference began to depart from the straight line by more than one-hundred-thousandth inch per inch strain. In a few cases, the permanent set was measured after each load.

\section{RESULTS}

Figures 4 and 5 are typical stress-strain curves up to the yield point. Though these figures show results for two transverse specimens, the curves are representative of the results found for all speciments. Table 3 gives the results derived from the stress-strain measurements. The values of the proportional limit there assigned are to be considered as dependent on the width of the error band that was assumed. The measurements indicated that the material was not perfectly elastic at low loads, but these departures from elasticity were of the same order as the random error in the readings, so that it remained uncertain to what extent this inelasticity was real. In any case, inelastic behavior before the yield point is of little signifcance in estimating the suitability of a material for structrual purposes. The yield point may therefore be taken as a measure of the safe working stress of the material. ${ }^{5}$

\footnotetext{
4 See Determination and Significance of the Proportional Limit in the Testing of Metals, R. L. Templin, and discussion, Proc., Am. Soc. Testing Materials, vol. 29, II, p. 523, 1929. Discussion, p. 538.

- See note 4.
} 


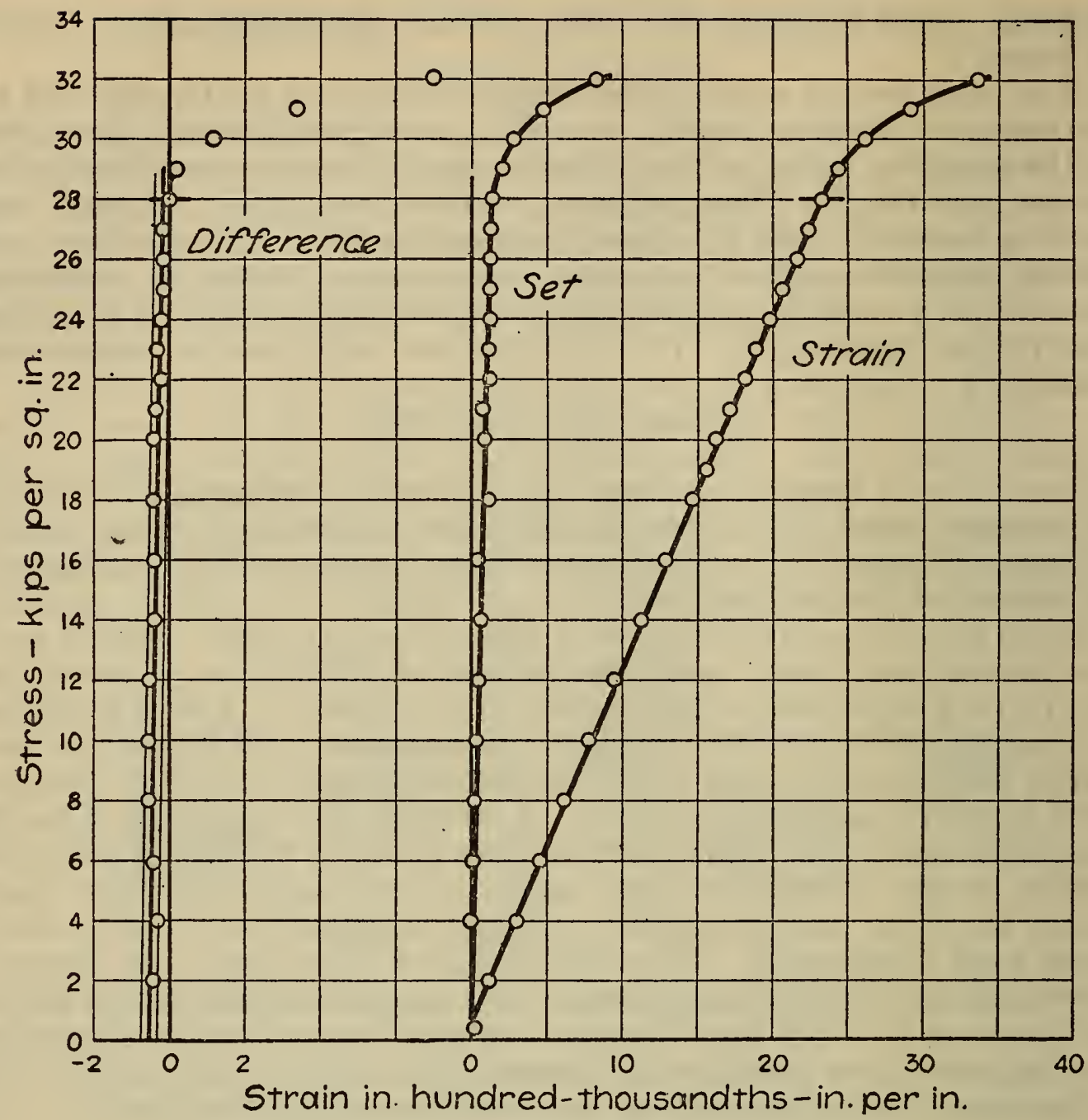

FIGURE 4.-Stress-strain curves for tensile specimen $9 T$

TABLE 3.-Results of stress-strain measurements on tensile specimens

\begin{tabular}{|c|c|c|c|c|c|c|}
\hline Specimen & $\begin{array}{c}\text { Thick- } \\
\text { ness }\end{array}$ & $\begin{array}{l}\text { Propor- } \\
\text { tional } \\
\text { limit }\end{array}$ & $\begin{array}{l}\text { Yield } \\
\text { point }\end{array}$ & $\begin{array}{l}\text { Tensile } \\
\text { strength }\end{array}$ & $\begin{array}{l}\text { Young's } \\
\text { modulus }\end{array}$ & $\begin{array}{l}\text { Elonga- } \\
\text { tion in } \\
2 \text { inches }\end{array}$ \\
\hline $\begin{array}{ll}1 & \mathrm{~L} \\
2 & \mathrm{~T} \\
3 & \mathrm{~L} \\
4 & \mathrm{~T} \\
5 & \mathrm{~T} \\
5 & \mathrm{~L}\end{array}$ & $\begin{array}{c}\text { Inch } \\
0.078 \\
.080 \\
.069 \\
.073 \\
.063\end{array}$ & $\begin{array}{r}\text { Kips/in. }{ }^{2} \\
14.7 \\
17.0 \\
8.6 \\
10.0 \\
20.1\end{array}$ & $\begin{array}{r}\text { Kips/in. }{ }^{2} \\
21.6 \\
22.7 \\
19.0 \\
21.2 \\
21.0\end{array}$ & $\begin{array}{r}\text { Kips/in. }{ }^{2} \\
39.7 \\
44.7 \\
39.9 \\
43.3 \\
40.2\end{array}$ & $\begin{array}{c}\text { Kips/in. }{ }^{2} \\
27,600 \\
29,600 \\
27,500 \\
29,100 \\
28,700\end{array}$ & $\begin{array}{r}\text { Per cent } \\
38 \\
33 \\
33 \\
31\end{array}$ \\
\hline $\begin{array}{l}6 \\
7 \\
8 \\
8 \\
9 \\
10\end{array}$ & $\begin{array}{l}.064 \\
.064 \\
.048 \\
.050 \\
.073\end{array}$ & $\begin{array}{l}12.4 \\
17.1 \\
27.4 \\
28.0 \\
20.2\end{array}$ & $\begin{array}{l}21.1 \\
29.0 \\
35.1 \\
33.9 \\
24.6\end{array}$ & $\begin{array}{l}39.4 \\
48.7 \\
51.4 \\
56.0 \\
45.8\end{array}$ & $\begin{array}{l}28,700 \\
28,900 \\
28,400 \\
29,800 \\
29,400\end{array}$ & $\begin{array}{l}32 \\
27 \\
25 \\
25 \\
38\end{array}$ \\
\hline $\begin{array}{ll}11 & \mathrm{~L} \\
12 & \mathrm{~T} \\
13 & \mathrm{~L} \\
14 & \mathrm{~T} \\
15 & \mathrm{~L} \\
\end{array}$ & $\begin{array}{l}.075 \\
.076 \\
.059 \\
.061 \\
.062\end{array}$ & $\begin{array}{l}16.0 \\
20.6 \\
29.0 \\
29.7 \\
18.0\end{array}$ & $\begin{array}{l}21.0 \\
27.8 \\
30.4 \\
35.2 \\
32.9\end{array}$ & $\begin{array}{l}40.7 \\
45.0 \\
43.7 \\
45.1 \\
46.2\end{array}$ & $\begin{array}{l}28,000 \\
29,900 \\
28,800 \\
29,300 \\
29,900\end{array}$ & $\begin{array}{l}36 \\
35 \\
31 \\
40 \\
36\end{array}$ \\
\hline $\begin{array}{l}16 \mathrm{~L}{ }^{2}-\ldots \ldots \\
17 \mathrm{~T} \\
18 \mathrm{~L} \\
19\end{array}$ & $\begin{array}{l}.045 \\
.047 \\
.049 \\
.050\end{array}$ & $\begin{array}{l}20.1 \\
15.4 \\
25.0 \\
24.6\end{array}$ & $\begin{array}{l}25.1 \\
31.3 \\
25.0 \\
28.5\end{array}$ & $\begin{array}{l}46.0 \\
55.8 \\
47.6 \\
51.4\end{array}$ & $\begin{array}{l}28,400 \\
31,400 \\
28,600 \\
30,600\end{array}$ & $\begin{array}{r}-\overline{25} \\
33 \\
30\end{array}$ \\
\hline
\end{tabular}

1 Considerable set at low loads.

2 Broke near gage mark. 
The average for 10 specimens of Young's modulus in the direction of rolling was $28,500,000 \mathrm{lbs}$./in. ${ }^{2}$, and transverse to the direction of rolling the average of nine tests was $29,700,000 \mathrm{lbs}$./in. ${ }^{2}$ A value of $28,700,000 \mathrm{lbs}$./in. ${ }^{2}$ was taken for the longitudinal modulus, this being arrived at by neglecting two specimens (1L and $3 \mathrm{~L}$ ), for which the elastic limit appeared to be particularly low.

Based on strength and yield-point determinations, the material was of three types:

1. Sheets having yield points of 20 to $28 \mathrm{kips} / \mathrm{in}^{2}$ (one kip equals 1,000 pounds) and tensile strengths of 38 to 48 kips/in. ${ }^{2}$ The elonga-

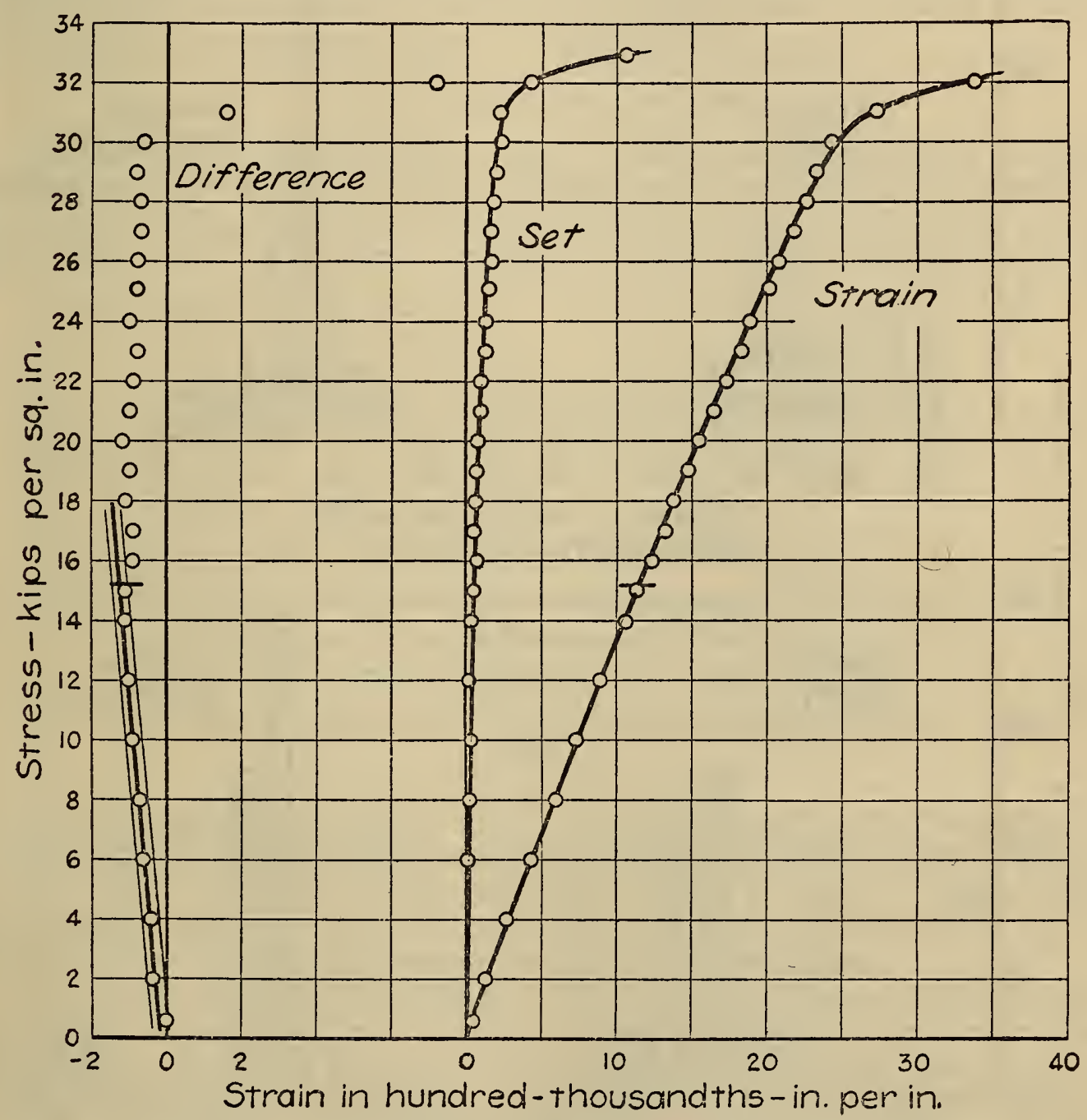

FIgURE 5.-Stress-strain curves for tensile specimen $17 T$

tion in 2 inches ranged from 30 to 40 per cent. At the yield point there was a sharp drop of beam, the load falling off considerably;

2. Sheets having yield points of 35 to $47 \mathrm{kips} / \mathrm{in}^{2}{ }^{2}$ and tensile strengths of 46 to $50 \mathrm{kips} / \mathrm{in}^{2}{ }^{2}$ There was a marked drop in load at the yield point. The elongation was as great as for the first type;

3. Sheets having tensile strengths of 50 up to $70 \mathrm{kips} / \mathrm{in} .{ }^{2}$ and a lower elongation than the preceding types. The yield points ranged from 29 to $52 \mathrm{kips} / \mathrm{in} .^{2}$ The elongations were in the neighborhood of 25 per cent. At the yield point the drop of beam was not so pronounced and occasionally the load remained nearly constant. 
Only a small proportion of the specimens were of the third type and these were all from 16 and 18 gage material. The higher strength appears to be due to cold working at the mill. The second type of sheet was made from open-hearth steel rolled on a continuous strip mill.

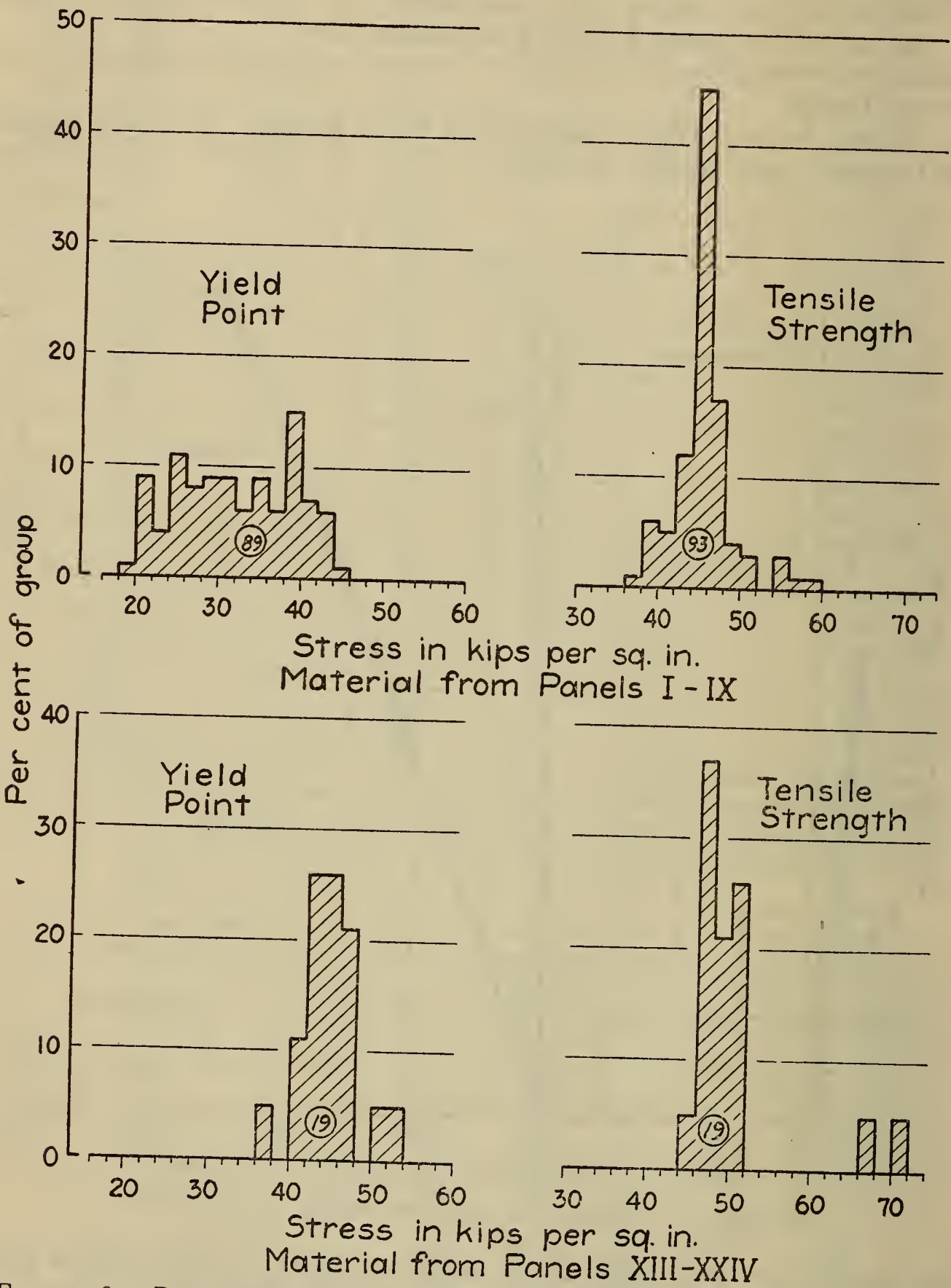

FIgURE 6.-Distribution of yield point and tensile strength among the speci-

The first type of material was found only in the first 12 panels, which also included some of the second type. All but one of the tensile coupons taken from panels XII through XXIV were of the second type, the exception being a 16-gage sheet of the third type.

Figure 6 shows graphically how the yield point and tensile strength were distributed among the specimens. 
The ordinate represents the per cent of the group which falls within the range of $2 \mathrm{kips} / \mathrm{in}^{2}{ }^{2}$ indicated on the horizontal scale. The ringed number is the total of specimens in each group.

\section{SHEARING STRENGTH OF THE WELDS}

\section{GENERAL}

The loads applied to the top surface of the floor panels caused shearing forces on the welds joining the top and bottom elements. It is obviously of importance to know what shears may be safely applied to spot welds such as those used in the cellular floor. A series of tests were conducted to obtain data on this point.

\section{METHODS OF TESTING}

The test of a spot-welded joint in shear alone presents certain difficulties. If a joint with a single lap is pulled in tension, the eccentric loading produces a couple tending to rotate the join of the two parts. In sheet metal this tends to split the joint apart and to

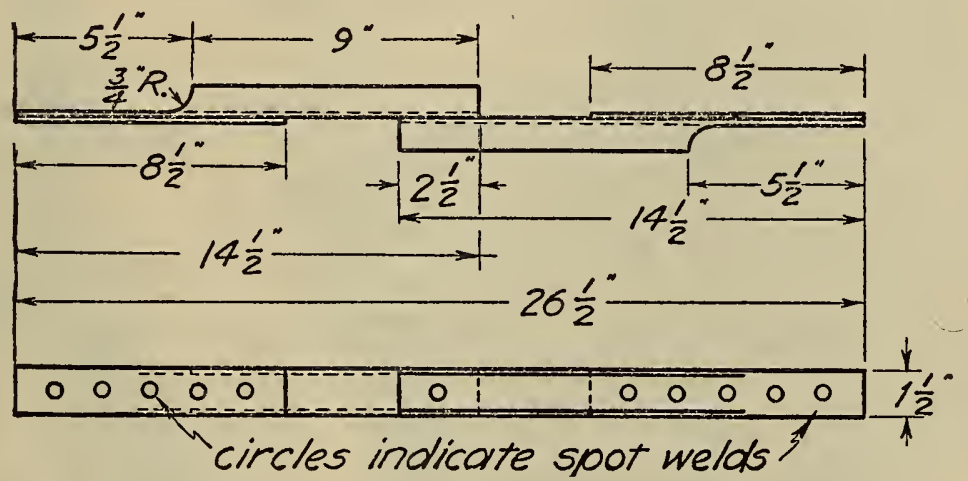

FIGURE 7.-Specimen for determining shearing strength of welds

produce buckles about the weld. If a double lap is used, the strength of the joint is considerably increased and fracture may occur outside of the welds; in fact, double lap joints in 14, 16, and 18 gage sheet containing two $3 / 8$-inch diameter welds were tested to destruction and all broke by tearing of the strip inside the cover plates.

A variety of joints containing 1,2 , and 3 welds were obtained and tested in tension. From these results a satisfactory specimen was designed as shown in Figure 7. ' It consists essentially of two channelshaped sections from the steel sheet lapped back to back and welded with a single spot. In order to grip the specimen in the jaws of the testing machine, the channel flanges were cut away at the ends. It was found necessary to reinforce the gripped portion of the specimen by welding on a strip along the back of each channel. The specimens were projection welded using a technique as close as possible to the welding methods used in fabricating floor. Such specimens in 14, 16, and 18 gage sheet containing one $3 / 8$-inch diameter spot weld fractured in the weld without appreciable bending of the channels or buckling of the sheet about the weld.

The specimens were tested in tension in a 100,000-pound Amsler machine using the 10,000-pound range. The autographic recording apparatus supplied with the machine was used on an 8-inch gage length, so that a load-extension curve was obtained in each case. 


\section{RESULTS}

The specimens described in the preceding section are noted below by the type letter $\mathrm{G}$, followed by the gage number of the sheet, and an individual specimen number to distinguish those of the same gage. Six specimens each of 14,16 , and 18 gage sheet were tested. The results are summarized in Table 4.

The gross area of the fractured surface of welds was estimated by assuming an elliptical shape and measuring two perpendicular diameters to the nearest 0.01 inch. The net area was obtained from the gross area by deducting for the larger blowholes. Both figures are, of course, only approximate, as are also in corresponding degree the stresses derived from them. The maximum load is definitely the
more significant figure.

The autographic records showed that failures were preceded by little or no plastic deformation. The single exception to this was G18-3, which failed by the weld tearing out of the sheet. The ultimate strength of the weld is therefore a measure of the permissible
design loads.

TABLE 4.-Strength of welds

\begin{tabular}{|c|c|c|c|c|c|c|}
\hline Specimen & Type of failure & $\begin{array}{l}\text { Maxi- } \\
\text { mum } \\
\text { load }\end{array}$ & $\begin{array}{c}\text { Gross } \\
\text { area } \\
\text { of } \\
\text { weld }\end{array}$ & $\begin{array}{l}\text { Net area } \\
\text { of weld }\end{array}$ & $\begin{array}{l}\text { Shearing } \\
\text { strength } \\
\text { on gross } \\
\text { area }\end{array}$ & $\begin{array}{l}\text { Shearing } \\
\text { strength } \\
\text { on net } \\
\text { area }\end{array}$ \\
\hline 14 & \multirow{2}{*}{$\begin{array}{l}\text { Negative bearing } \\
\text { Shear } \\
\text { do }\end{array}$} & \multirow{2}{*}{$\begin{array}{l}\text { Kips } \\
4.59 \\
3.39 \\
4.02 \\
3.86 \\
3.64\end{array}$} & $\begin{array}{l}\text { Square } \\
\text { inch }\end{array}$ & $\begin{array}{l}\text { Square } \\
\text { inch }\end{array}$ & Kips/in..$^{2}$ & Kips/in. ${ }^{2}$ \\
\hline $\begin{array}{l}\text { G14-3.- } \\
\text { G14-4... } \\
\text { G14-5... }\end{array}$ & & & $\begin{array}{r}0.105 \\
.119 \\
.101 \\
.095\end{array}$ & $\begin{array}{l}0.102 \\
.117 \\
.099 \\
.087\end{array}$ & $\begin{array}{l}-32.3 \\
33.8 \\
38.2 \\
38.3\end{array}$ & $\begin{array}{l}33.2 \\
34.4 \\
39.0 \\
41.8\end{array}$ \\
\hline $\begin{array}{l}\text { G14-6-. } \\
\text { G16-1-- } \\
\text { G16-2- } \\
\text { G16-3-- }\end{array}$ & 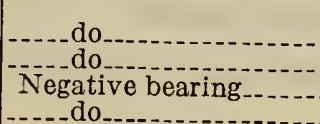 & \multirow{2}{*}{$\begin{array}{l}3.75 \\
2.94 \\
2.61 \\
2.57 \\
2.24\end{array}$} & \multirow[t]{2}{*}{.108} & .074 & \multirow[t]{2}{*}{$\begin{array}{l}34.7 \\
39.2\end{array}$} & \multirow[t]{2}{*}{$\begin{array}{l}36.1 \\
39.7\end{array}$} \\
\hline G16-4 & -...-do- & & & & & \\
\hline & \multirow{3}{*}{$\begin{array}{l}\text { Shear } \\
\text { Negative bearing } \\
\text { Shear }\end{array}$} & \multirow{3}{*}{$\begin{array}{l}2.43 \\
2.49 \\
2.91 \\
2.83\end{array}$} & \multirow[b]{2}{*}{.058} & \multirow[b]{2}{*}{.055} & \multirow[b]{2}{*}{42.9} & \multirow[b]{2}{*}{45.3} \\
\hline & & & & & & \\
\hline & & & .104 & $0.057-0.090$ & 27.2 & $31.4-49.6$ \\
\hline $\begin{array}{l}\text { G18-3-- } \\
\text { G18-4 }\end{array}$ & Negative bearing-- & $\begin{array}{l}2.81 \\
3.09\end{array}$ & 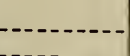 & & & \\
\hline & $\begin{array}{l}----d \\
\cdots---d\end{array}$ & $\begin{array}{l}2.87 \\
3.14\end{array}$ & $\cdots$ & & & (n) \\
\hline & & 0.14 & & & & \\
\hline
\end{tabular}

Those specimens in which the weld metal itself did not shear failed by the weld spot tearing out of the sheet. On the side of a weld toward the gripped end of that portion of the specimen there exists a concentrated tensile "negative bearing stress," analogous to the compressive bearing stress in the plate of a riveted joint. Where compressive failure occurs in the plate in the riveted joint, the material in each sheet parts in tension in the welded joint. Failure progresses by the welded regions twisting and tearing out of the sheets. Figure 8 shows late stages in the failure in "negative bearing" of two 16-gage specimens, one single-lap and one channel type. Some of the failures of this kind appeared to start in defective material near the edge of the weld and then spread to the edge of the unfused
material. 


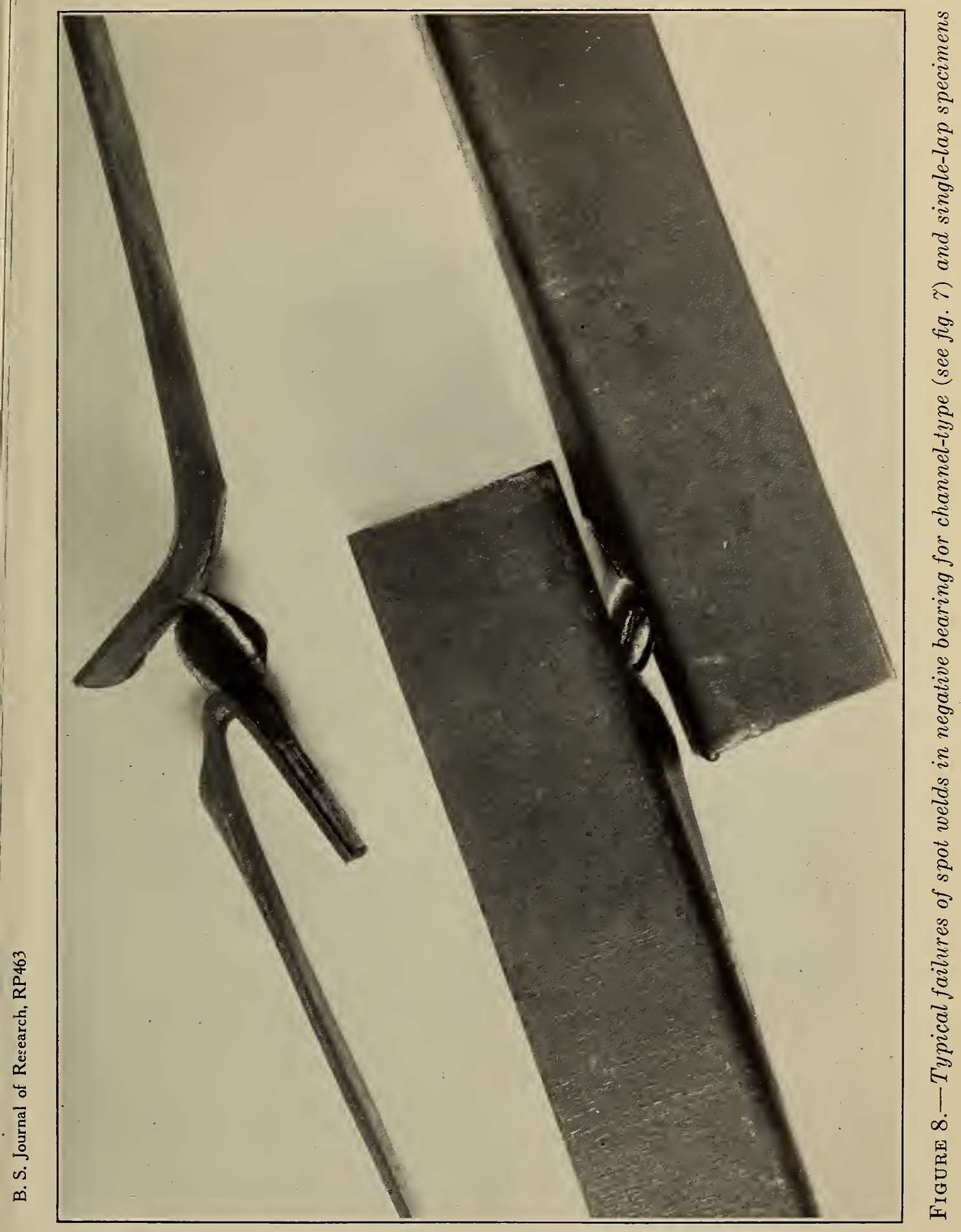


B. S. Journal of Research RP463

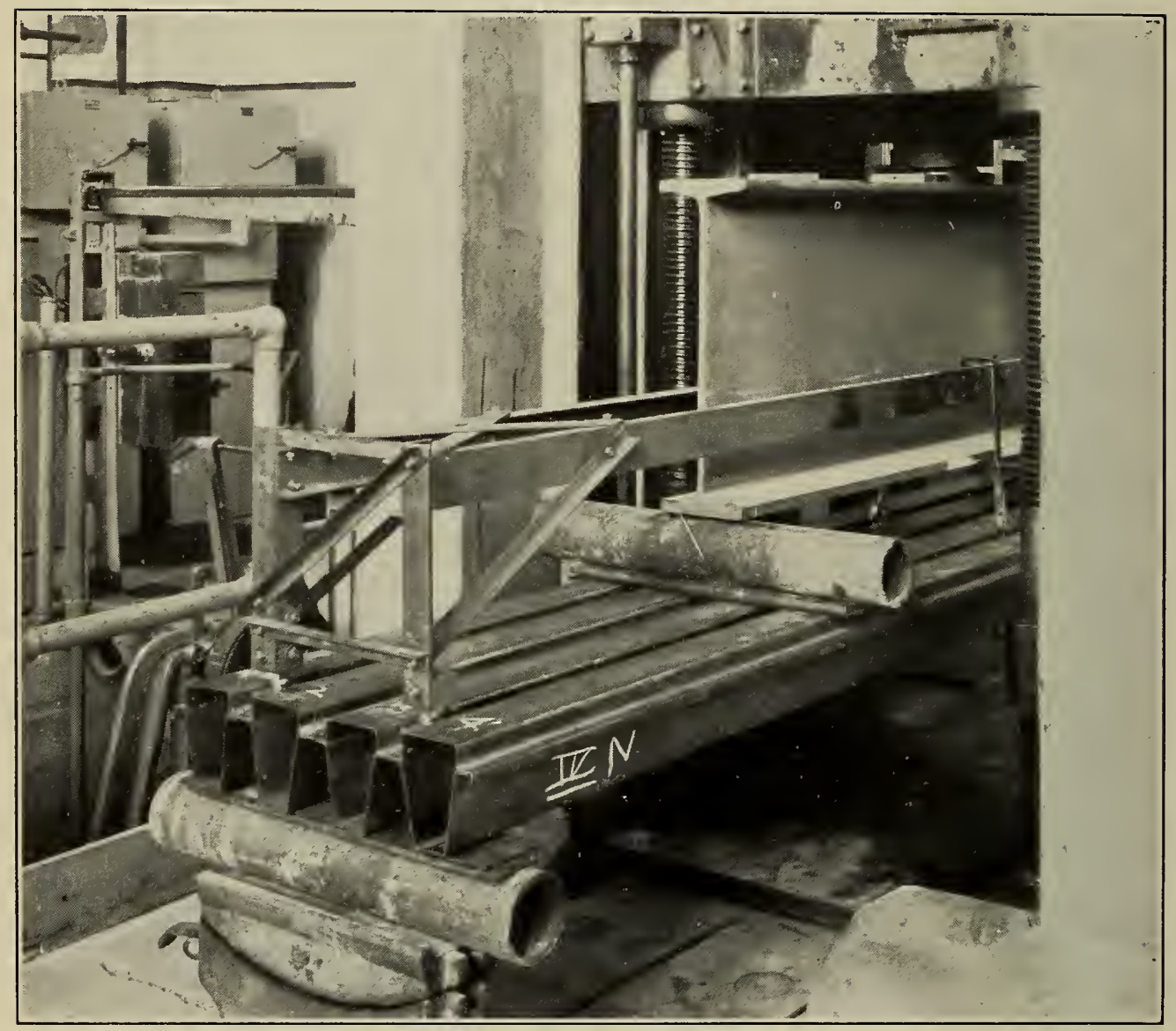

Figure 9.-View of a floor panel ready for test 
The fractures of welds that broke in shear presented a variety of appearances. The welding of specimens G16-1 and G16-6 was defective, the former containing three weld spots of gross areas 0.019 , 0.008 , and 0.048 square inch, and the latter containing two spots of gross areas 0.013 and 0.045 square inch. Apparently the sheets were in good electric contact at more than one place due to a poorly made projection or to uneven surfaces. The welds in both specimens contained oxide inclusions. The weld in G18-2 contained coarse radial blowholes about the periphery, there being also a central region with large voids. Tarnish in the center suggests that there was poor adhesion in that portion, but the tarnish may possibly have occurred following fracture. In the 14-gage specimens all the sheared welds contained blowholes, in some cases only one at the center, while in others there were many fine radial blowholes. In the latter cases the surface of fracture showed considerable curvature through points of weakness. Where the weld contained only a few circular blowholes, the fracture presented the appearance of a broken piece of coarsegrained ductile material.

Application of conclusions drawn from these tests must necessarily be restricted to material of the same grade of sheet steel and to welds of the same size made under similar conditions. Higher-strength material would be expected to show higher values, at least in negative bearing.

It is evident that the gage and the tensile strength of the sheet determine whether shearing or negative bearing failure will occur. Below a certain thickness the concentration of tensile stress at the edge of the weld will produce negative bearing failure before the shearing strength of the weld is reached. Above this thickness the load required to shear the weld will not produce the requisite tensile stress to produce a failure in negative bearing. The specimens may be distinguished on this basis. The 16 and 18 gage specimens all broke in negative bearing with the exception of G16-1, G16-6, and G18-2, in which the welds were defective. The 14-gage specimens broke by shearing of the weld, the sole exception to this being G14-1, in which the weld was evidently of much greater shearing strength. In general, then, material of 14 gage or heavier may be expected to develop the full shearing strength of these welds while lighter gages will fail at lower loads in negative bearing.

The shearing strength developed in a welded joint thus depends upon the gage of the sheet when the gage is below a certain critical thickness. Above that thickness the strength should be independent of the gage. Though the tensile properties of the sheet used in the weld specimens were not determined, there was general evidence through the tests that the 16-gage material was of rather low strength, so that the low figures for the 16-gage specimens compared to the 18gage specimens is probably to be explained on these grounds. The specimen of lowest strength was G16-4 which broke at 2.24 kips in negative bearing, this being a lower breaking load than observed from the specimens with defective welds previously described. Two kips would thus be a conservative figure for the strength of a single one of these spot welds in shear. 


\section{METHOD OF TESTING FLOOR PANELS}

\section{INFORMATION DESIRED}

The most important points to be ascertained in the tests of the floor panels themselves were: First, how closely do the deflections and stresses agree with those calculated by the Euler-Bernoulli theory, which is usually used in designing engineering structures; and second, under what range of loads does the floor behave elastically? It is further of importance to know how failure occurs and what are the points of structural weakness with their effects on the response of the panel to load.

It was decided therefore to make transverse tests to destruction of the individual floor panels, measuring deflections and strains at suitable locations in order to correlate these with the loads.

\section{TEST PROCEDURE}

The test panels were mounted at the ends on roller supports. The A12-12 specimens were 10 feet in length and were tested on a span of 9 feet 8 inches; the remaining panels were 11 feet long and were tested when possible on a span of 10 feet, it being necessary to use a span of 10 feet 6 inches for the type $C$ specimens and the type $A$ specimens with reinforcing at the ends of the cell bottoms (A16-18). In each case the specimen had a length of bearing of 4 inches. Equal loads were applied at the quarter points of the span in a screw powertesting machine of 600,000 -pound capacity, using a poise giving a 300,000 -pound range. By loading at the quarter points the bending moment between the loads was uniform and equal to the maximum moment which would be produced by the load uniformly distributed. The maximum shear is likewise equal to the maximum shear produced by uniform loading. The computed deflection at mid-span, however, is 10 per cent greater than would have been produced by uniform loading. Since the maximum bending moment is developed over the middle half of the span and the maximum shear is developed over the portions of the specimen between the loads and the supports, inhomogeneities in the structure will be more liable to discovery than if the panel were uniformly loaded.

Steel bearing plates with pads of $1 / 4$-inch canvas belting were used to distribute the loads and reactions to the specimen. The plates were 4 inches wide and one-half inch thick and extended across the specimen, the pads being cut to the same size and placed between the specimen and the bearing plate. The load was transmitted to the -specimen from the movable cross head of the machine by an I beam carried on a spherical bearing, rollers being placed between the loading beam and the bearing plates. This arrangement can be seen in the typical set-up shown in Figure 9. In the figure it will be noticed that the end bearings are free to accommodate themselves to small twists in the specimen by means of a cylindrical seating.

The deflection at mid-span was measured at each load by means of dial micrometers accurate to 0.002 inch. These dials were mounted on a stiff frame supported at the horizontal webs of the panel immediately over the supports. The frame was carried on 3 steel balls in such a way that 1 foot was free to rotate about a point, 1 to move along a line, and 1 to move in a plane, the support being therefore 


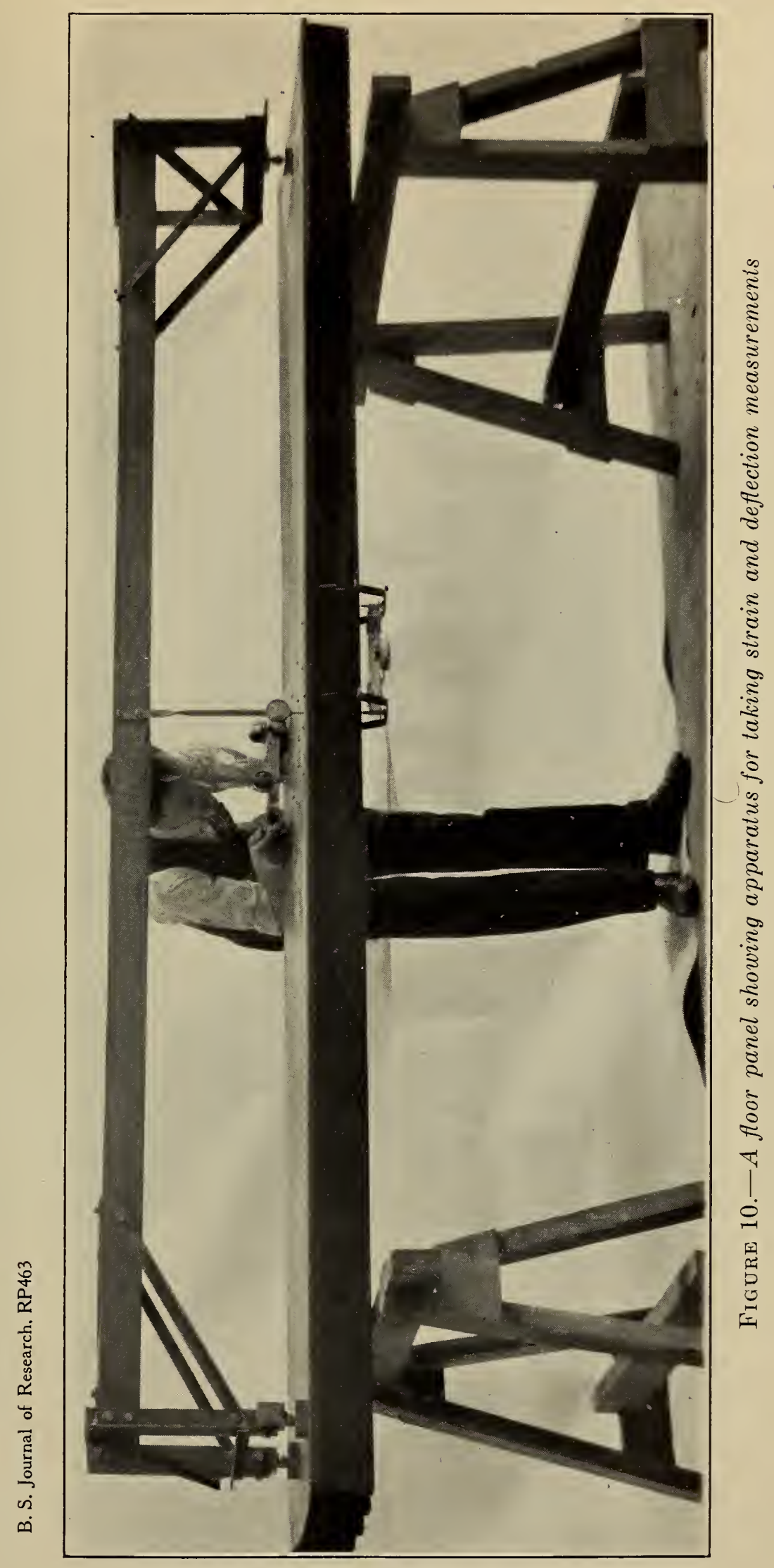


B. S. Journal of Research, RP463

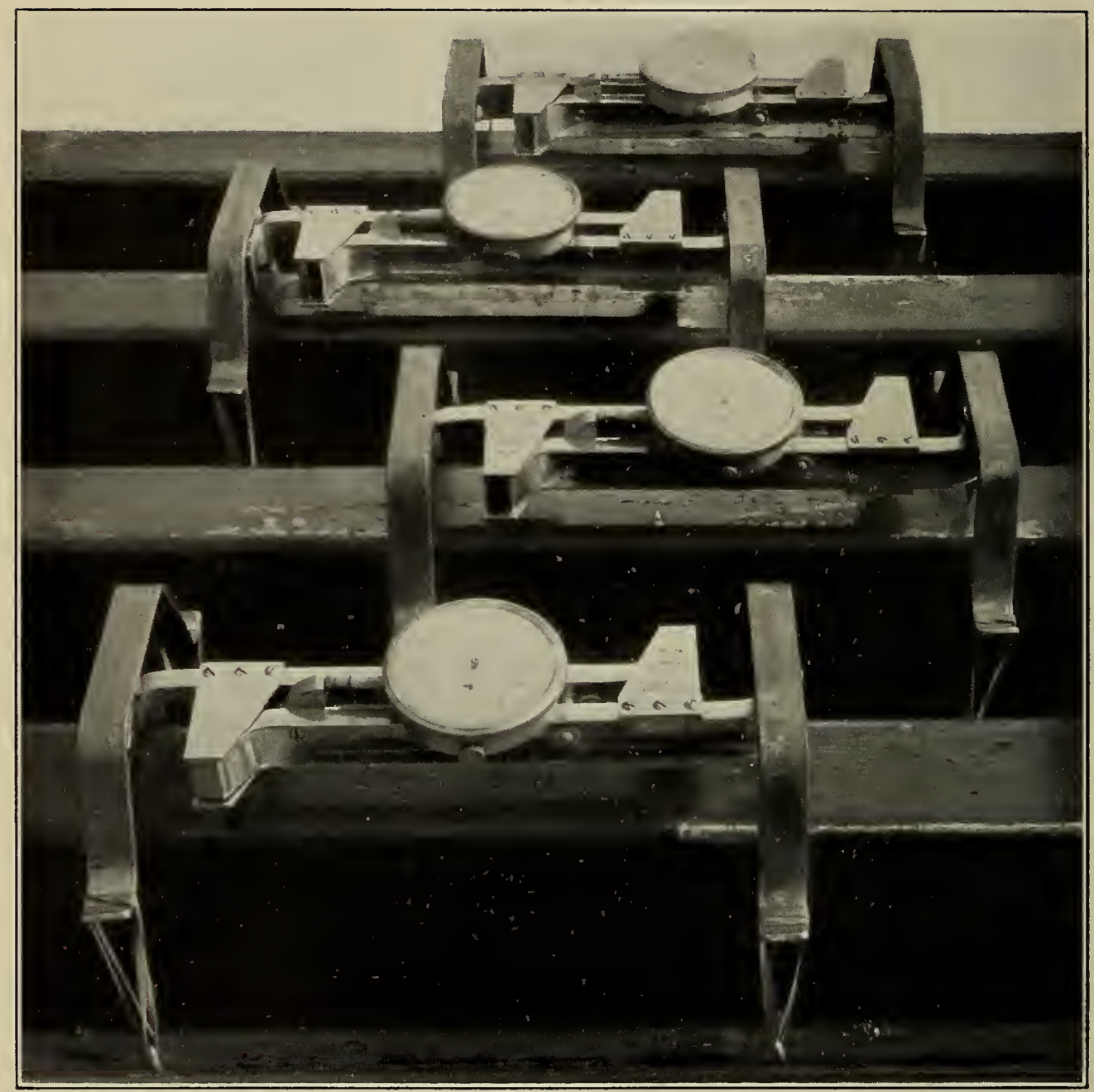

Figure 11.-Bottom of a floor panel showing arrangement of strain gages 
kinematically nonredundant. This frame and its mounting is shown in Figures 9 and 10 . Such a mounting assures the frame remaining unstrained during all portions of the test. The deflection was therefore measured unambiguously relative to a plane close to the neutral surface of the panel, this neutral surface being computed to lie seveneighths to 1 inch below the web for specimens of types $A$ and $C$, and $1 \% 2$ inches below the web for type B specimens. The deflection was taken on the webs at mid-span at two points 6 inches on either side of the center line.

The strains on a 10-inch gage length in the top and bottom of each cell were measured, also at mid-span, by the use of Whittemore hand strain gages. ${ }^{6}$ These gages read to a ten-thousandth of an inch and the readings can be estimated to a hundred-thousandth of an inch, "which corresponds to a stress of about $30 \mathrm{lbs} . / \mathrm{in} .{ }^{2}$ The error in the strain gages is believed not to exceed two divisions (600 lbs./in. ${ }^{2}$ equivalent stress), this error being due for the most part to irregularities in the dial mechanism. The readings on the top of the panel, the compression side, were taken by the customary hand application of the gage as illustrated in Figure 10, while the readings on the bottom were taken with instruments attached to the specimen with rubber bands. Details of the method of attaching the bottom gages can be seen in Figure 11. The gage lengths on the bottom were staggered two inches alternately on either side of the mid-span for convenience in attaching the instruments.

According to the conventional engineering theory, the stresses in the extreme fibers should be constant between the loads, this being due to the constancy of bending moment and section modulus. The stresses were computed by multiplying the strain by the average value of Young's modulus $\left(28,700,000\right.$ lbs./in. $\left.{ }^{2}\right)$ found in the tensile tests of the material.

The height of each cell at the two ends of the specimen was measured to the nearest hundredth of an inch by means of internal calipers at each load for which the top strain gages were read.

The usual procedure in a test consisted of taking cell heights, top and bottom strain-gage readings, and deflection measurements with no load on the panel. These readings were repeated at 2,000-pound intervals. The deflection dials and bottom strain gages were read at each 1,000-pound interval. In the case of the heaviest panels, XIX, $\mathrm{XX}$, and $\mathrm{XXI}$, of the A12-12 type, readings were made every 1,500 pounds; for all other specimens readings were taken every 1,000 pounds. The first group of 12 panels contained three specimens of each type. One of these was loaded in 1,000-pound increments straight up to the point at which it would support no added load. Strain-gage readings were taken until the change in gage length indicated that the material was well beyond its elastic range. The deflection measurements were taken over the full range of the apparatus (about $13 / 4$ inches), which sufficed to carry the readings nearly to the maximum load. A second specimen of the same type was loaded until a "limiting deflection" was reached approximately equal to one three hundred and sixtieth of the span plus 10 per cent. As previously mentioned, the loading in the tests should produce a deflection 10

6 See Arch Dam Investigation, vol. 1, Am. Soc. Civil Engrs., p. 64; November, 1927.

$127984-32-3$ 
per cent greater than the same load uniformly distributed. In order to avoid cracking plaster ceilings, floors are generally restricted to a maximum deflection when uniformly loaded of one three hundred and sixtieth of the span. The limiting deflection of the tests consequently corresponds to the deflection limits set on floors in practice. At this load the specimen was held for one hour to observe any creep that might occur. Following this halt, the test was continued to failure as before. The third panel of the group was loaded up to the limiting deflection with the same load increments as before, then unloaded in steps to zero, readings being taken at the same loads as in the first portion of the test. The rest of the test then continued as for the

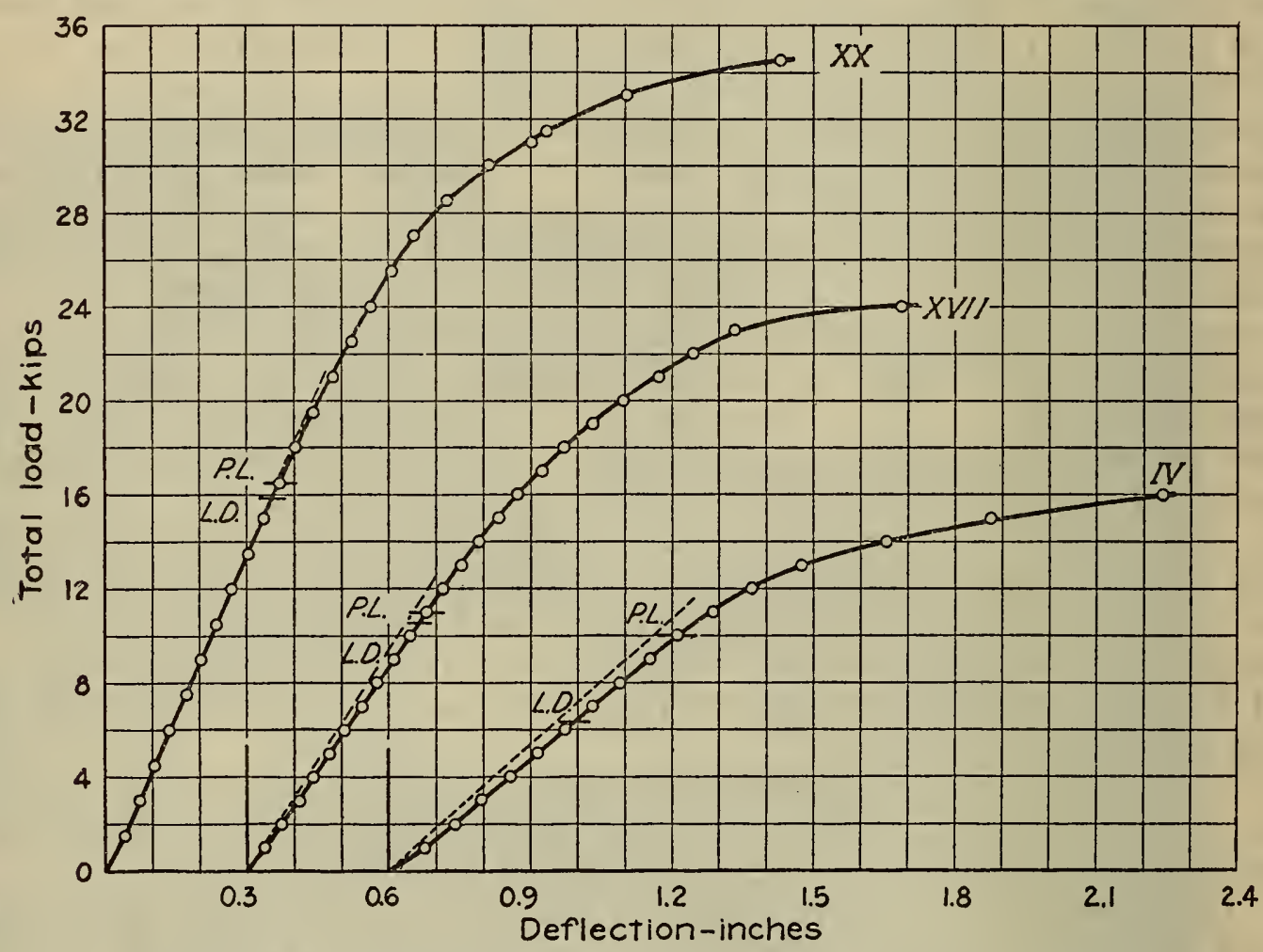

Figure 12.-Load-deflection curves for panels $I V, X V I I$, and $X X$

first specimen. The object of this repeated loading was to observe hysteresis effects as well as permanent set on removing the load. Any effects of prestressing should show up on the second loading. Since secondary effects were found to obscure any real hysteresis that may have been present, the procedure followed for the last 12 specimens was to load to the limiting deflection, unload to zero to observe permanent set, no intermediate readings being taken during unloading, then reload to the limiting deflection and continue the test as before. To observe creep, one specimen of each group was held for an hour at the limiting deflection load before unloading.

Careful watch was maintained to observe the development of buckling failure in the various parts of the specimen, the principal points of interest being the cell tops at and between the loads and the side walls of the cells at the supports. 


\section{RESULTS OF THE PANEL TESTS}

The curves of Figures 12 and 13 show typical relations of load to average deflection at mid-span. It will be observed that up to a certain point on the curves, the deflection is proportional to the load within the experimental error. This was found to be true for all the specimens. The load at this point will be spoken of subsequently as the proportional limit of the floor panel. The proportional limit for the panel is indicated on the curves by P. L. and the limiting deflection load by L. D. A deviation of 0.002 inch from proportionality was taken as criterion for determining this limit. The proportional limit of the panel so defined and the load at the limiting defiection

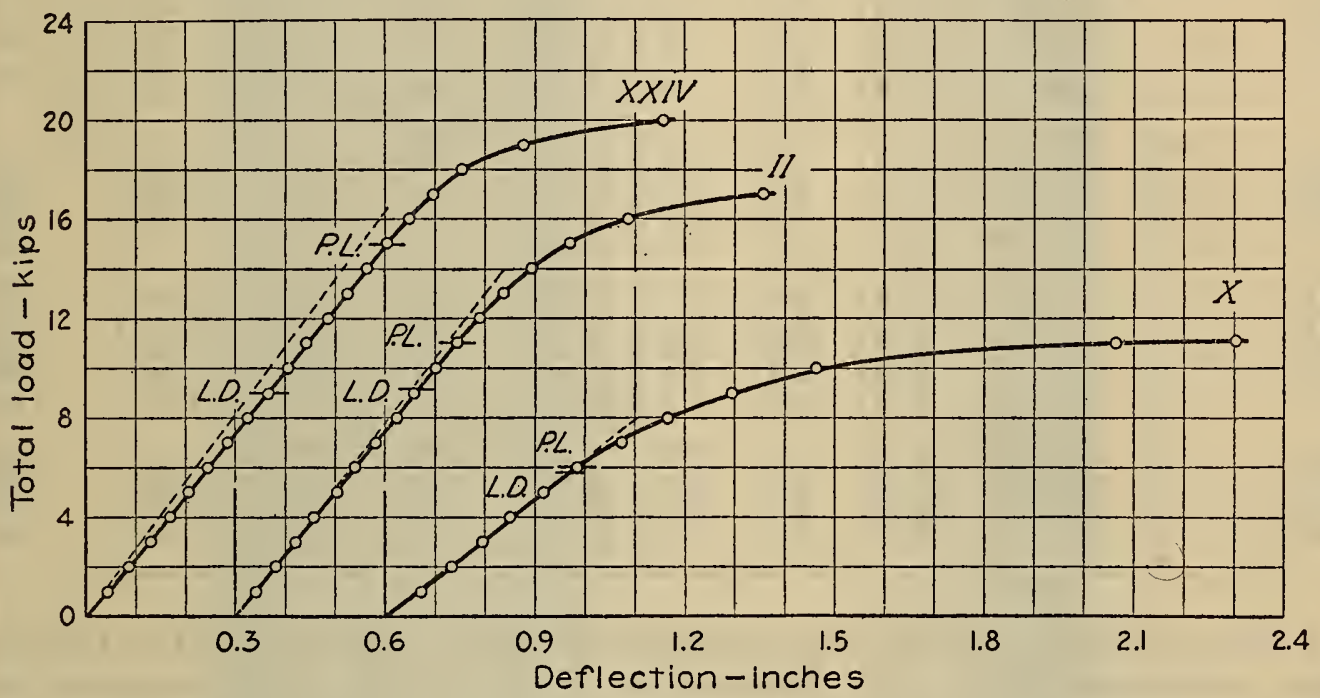

FIgURE 13.-Load-deflection curves for panels $I I, X$, and $X X I V$

of the panels are used as a basis for discussing their behavior. For this reason these points are also marked on succeeding curves. Above the proportional limit the deflection increases more rapidly with successive increments of load, this being due to plastic yielding and to buckling. This yielding progresses until a point is reached where the panel will support no added load. Specimens remained intact, though deformed, after the test. Figures 14 to 17 show the appearance of some typical panels after testing.

Table 5 summarizes the strength properties of the specimens and gives also the spans on which they were tested and the permanent set indicated by the deflection dials when unloaded completely from the limiting deflection. The columns headed equivalent uniform loads per square foot give the distributed loads which were computed to give the same maximum bending moment on a 10-foot span as the observed loads. 
TABLE 5.-Strength properties of panels

\begin{tabular}{|c|c|c|c|c|c|c|c|c|c|}
\hline \multirow{2}{*}{ Panel No. } & \multirow{2}{*}{$\begin{array}{l}\text { Descrip- } \\
\text { tion }\end{array}$} & \multirow{2}{*}{ Span } & \multirow{2}{*}{$\begin{array}{l}\text { Limit- } \\
\text { ing de- } \\
\text { flection } \\
\text { load }\end{array}$} & \multirow{2}{*}{$\begin{array}{l}\text { Propor- } \\
\text { tional } \\
\text { limit }\end{array}$} & \multirow{2}{*}{$\begin{array}{l}\text { Maxi- } \\
\text { mum } \\
\text { load }\end{array}$} & \multicolumn{3}{|c|}{$\begin{array}{l}\text { Equivalent uniform load on } \\
10 \text {-foot span }\end{array}$} & \multirow{2}{*}{$\begin{array}{l}\text { Set after } \\
\text { loacling } \\
\text { to limit- } \\
\text { ing deflec- } \\
\text { tion }\end{array}$} \\
\hline & & & & & & $\begin{array}{l}\text { Limiting } \\
\text { deflec- } \\
\text { tion load }\end{array}$ & $\begin{array}{l}\text { Propor- } \\
\text { tional } \\
\text { limit }\end{array}$ & $\begin{array}{l}\text { Maxi- } \\
\text { mum } \\
\text { load }\end{array}$ & \\
\hline $\begin{array}{l}\text { III } \\
\text { IIV } \\
\text { IV } \\
\text { V.... }\end{array}$ & $\begin{array}{l}\text { A14-16 } \\
\text { A14-16 } \\
\text { A14-16 } \\
\text { A16-18 } \\
\text { A } 16-18\end{array}$ & $\begin{array}{cc}\text { Ft. } & \text { in. } \\
10 & 0 \\
10 & 0 \\
10 & 0 \\
10 & 6 \\
10 & 6\end{array}$ & $\begin{array}{r}\text { Kips. } \\
8.5 \\
9.2 \\
9.9 \\
6.2 \\
5.7\end{array}$ & $\begin{array}{r}\text { Kips. } \\
9.0 \\
11.0 \\
9.0 \\
10.0 \\
11.0\end{array}$ & $\begin{array}{l}\text { Kips. } \\
18.61 \\
17.65 \\
16.99 \\
17.25 \\
17.00\end{array}$ & $\begin{array}{r}\text { Lbs./ft. }{ }^{2} \\
425 \\
460 \\
495 \\
326 \\
299\end{array}$ & $\begin{array}{r}\text { Lbs./ft. }{ }^{2} \\
450 \\
550 \\
450 \\
525 \\
578\end{array}$ & $\begin{array}{r}\text { Lbs./ft. }{ }^{2} \\
930 \\
882 \\
850 \\
906 \\
892\end{array}$ & $\begin{array}{c}\text { Inch } \\
0.008 \\
.010\end{array}$ \\
\hline $\begin{array}{l}\text { VI } \\
\text { VII } \\
\text { VIII } \\
\text { IX.- } \\
\text { X.-. }^{-}\end{array}$ & $\begin{array}{l}\text { A } 16-18 \\
\text { C14-16 } \\
\text { C14-16 } \\
\text { C14-16 } \\
\text { B } 16-16\end{array}$ & $\begin{array}{ll}10 & 6 \\
10 & 6 \\
10 & 6 \\
10 & 6 \\
10 & 0\end{array}$ & $\begin{array}{l}6.5 \\
7.5 \\
8.0 \\
8.4 \\
5.7\end{array}$ & $\begin{array}{l}6.5 \\
6.0 \\
8.2 \\
3.8 \\
6.0\end{array}$ & $\begin{array}{l}15.77 \\
13.67 \\
14.35 \\
15.30 \\
11.54\end{array}$ & $\begin{array}{l}341 \\
394 \\
420 \\
441 \\
285\end{array}$ & $\begin{array}{l}341 \\
315 \\
430 \\
200 \\
300\end{array}$ & $\begin{array}{l}828 \\
718 \\
753 \\
803 \\
577\end{array}$ & .016 \\
\hline $\begin{array}{l}\text { XI } \\
\text { XII } \\
\text { XIII } \\
\text { XIV } \\
\text { XV }\end{array}$ & $\begin{array}{l}\text { B16-16 } \\
\text { B16-16 } \\
\text { A14-16 } \\
\text { A16-18 } \\
\text { B16-18 }\end{array}$ & $\begin{array}{ll}10 & 0 \\
10 & 0 \\
10 & 0 \\
10 & 6 \\
10 & 0\end{array}$ & $\begin{array}{l}5.0 \\
5.2 \\
9.7 \\
6.5 \\
5.6\end{array}$ & $\begin{array}{r}5.0 \\
7.4 \\
8.0 \\
10.0 \\
8.0\end{array}$ & $\begin{array}{l}11.05 \\
13.32 \\
20.45 \\
18.05 \\
1400\end{array}$ & $\begin{array}{l}250 \\
260 \\
485 \\
341 \\
280\end{array}$ & $\begin{array}{l}250 \\
370 \\
400 \\
525 \\
400\end{array}$ & $\begin{array}{r}552 \\
666 \\
1,022 \\
948 \\
700\end{array}$ & $\begin{array}{l}.026 \\
.014 \\
.004 \\
.002\end{array}$ \\
\hline $\begin{array}{l}\text { XVI } \\
\text { XVII } \\
\text { XVIII } \\
\text { XIX } \\
\text { XX }\end{array}$ & $\begin{array}{l}\text { A14-14 } \\
\text { A14-14 } \\
\text { A14-14 } \\
\text { A12-12 } \\
\text { A12-12 }\end{array}$ & $\begin{array}{rl}10 & 0 \\
10 & 0 \\
10 & 0 \\
9 & 8 \\
9 & 8\end{array}$ & $\begin{array}{l}11.0 \\
10.6 \\
11.0 \\
15.3 \\
15.8\end{array}$ & $\begin{array}{l}\text { l11.0 } \\
11.0 \\
11.0 \\
19.5 \\
16.5\end{array}$ & $\begin{array}{l}25.65 \\
26.15 \\
25.65 \\
38.15 \\
38.20\end{array}$ & $\begin{array}{l}550 \\
530 \\
550 \\
739 \\
764\end{array}$ & $\begin{array}{l}550 \\
550 \\
550 \\
942 \\
797\end{array}$ & $\begin{array}{l}1,282 \\
1,308 \\
1,282 \\
1,844 \\
1,846\end{array}$ & $\begin{array}{l}.016 \\
.011 \\
.016 \\
.008 \\
.005\end{array}$ \\
\hline $\begin{array}{l}\text { XXY } \\
\text { XXII } \\
\text { XXIII. } \\
\text { XXIV }\end{array}$ & $\begin{array}{l}\text { A12-12 } \\
\text { A14-16 } \\
\text { A } 14-16 \\
\text { A14-16 }\end{array}$ & $\begin{array}{rl}9 & 8 \\
10 & 0 \\
10 & 0 \\
10 & 0\end{array}$ & $\begin{array}{r}16.4 \\
9.3 \\
9.9 \\
9.0\end{array}$ & $\begin{array}{l}16.5 \\
14.6 \\
14.8 \\
14.6\end{array}$ & $\begin{array}{l}36.14 \\
20.10 \\
21.80 \\
21.00\end{array}$ & $\begin{array}{l}793 \\
465 \\
495 \\
450\end{array}$ & $\begin{array}{l}797 \\
730 \\
740 \\
730\end{array}$ & $\begin{array}{l}1,747 \\
1,005 \\
1,090 \\
1,050\end{array}$ & $\begin{array}{l}.008 \\
.003 \\
.001 \\
.005\end{array}$ \\
\hline
\end{tabular}

For use in interpreting these results, section properties of the panels were calculated from the dimensions in Table 2. The moment of inertia, position of the neutral axis and section moduli were computed for each panel. In order to determine whether the use of average dimensions was justified in calculating these properties, the moment of inertia and position of the neutral axis was calculated cell by cell for some of the most irregular specimens. No appreciable differences, however, were found between the two methods of calculation. The dotted lines shown in the load-deflection and load-strain curves of the panels indicate the deflection calculated from these section properties.

The moment of inertia was also derived from the slope of the loaddeflection curve below the proportional limit. The slope was determined by the method of least squares which takes here a particularly simple form on account of the equal increments of load.

Table 6 gives the computed values of the section properties and also the observed values of the moments of inertia taken from the load-deflection curves. 

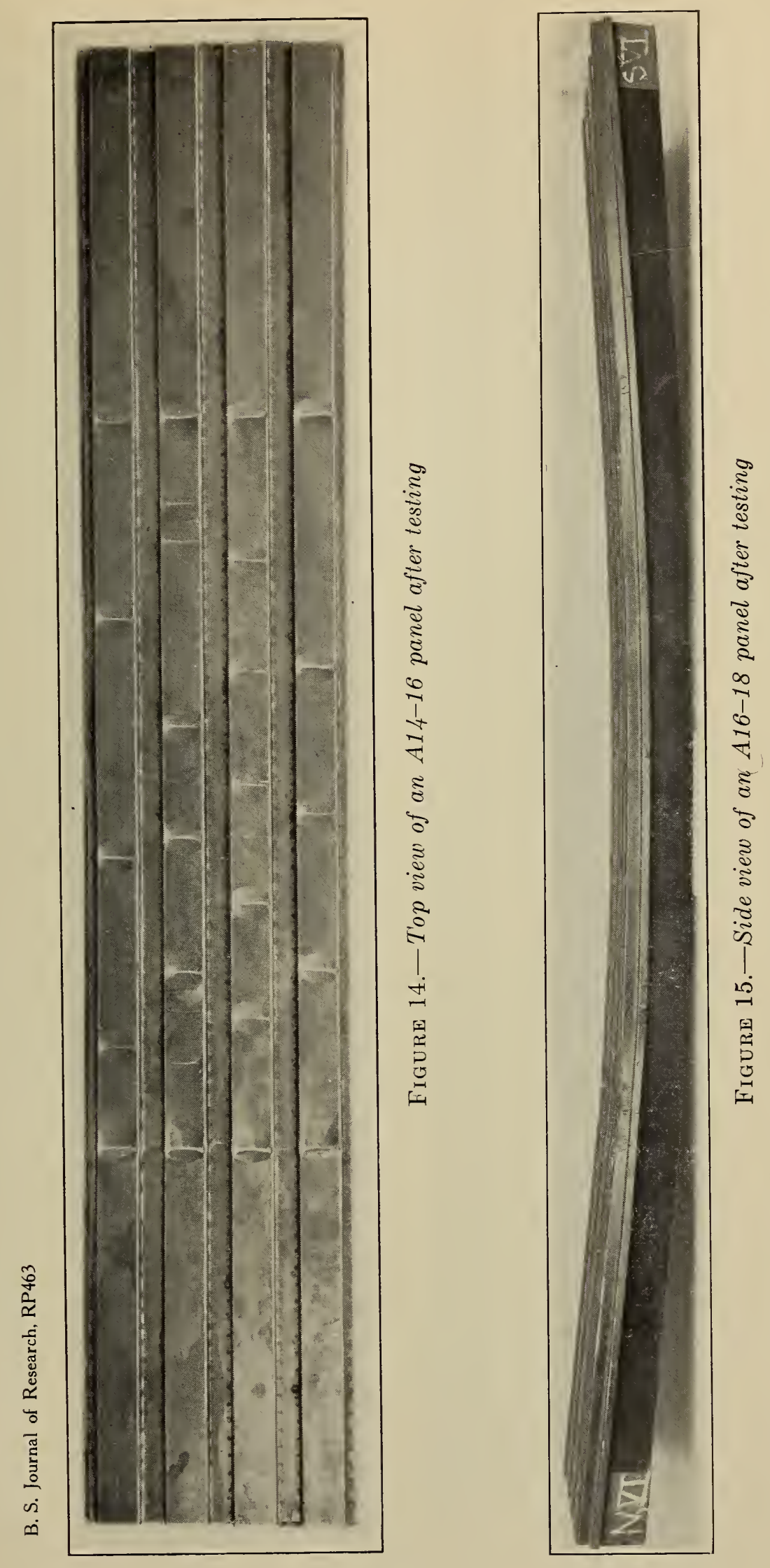

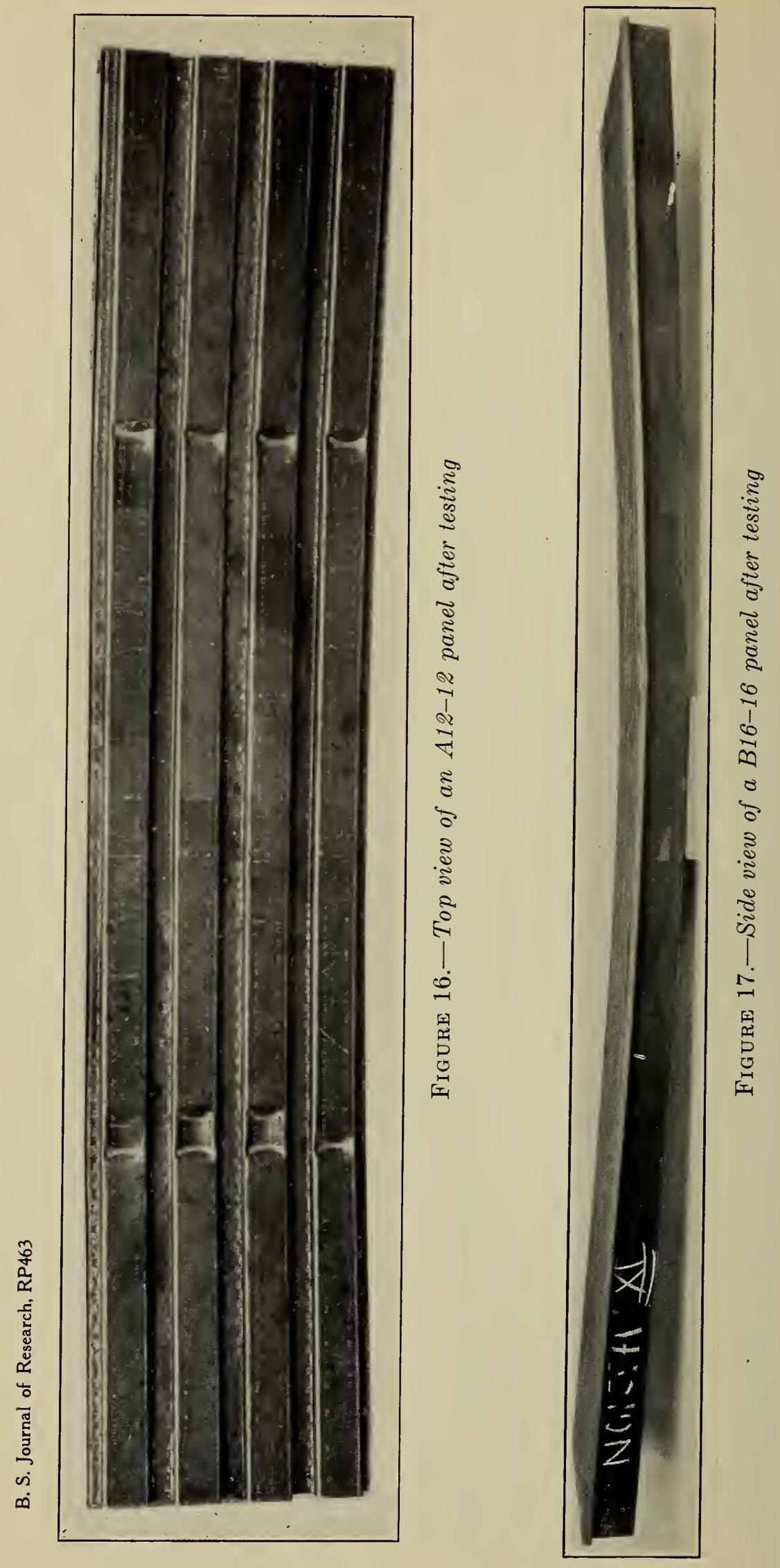
TABLE 6.-Section properties of panels

$S_{c}=$ compressive section modulus for panel.

$S_{t}=$ tensile section modulus for panel.

$v_{c}=$ distance from neutral axis to extreme compression fiber.

$v_{t}=$ distance from neutral axis to extreme tension fiber.

$r_{\mathrm{csle}}=\frac{v_{\mathrm{c}}}{v_{\mathrm{c}}+v_{i}}$.

$I=$ moment of inerita of panel.

\begin{tabular}{|c|c|c|c|c|c|c|c|c|}
\hline Panel & Type & $S_{c}$ & $S_{t}$ & $v_{c}$ & $v_{t}$ & $r$ (calc.) & $I$ (calc.) & $I$ (obs.) \\
\hline $\begin{array}{l}\text { I } \\
\text { II } \\
\text { III } \\
\text { IV } \\
\text { V }\end{array}$ & $\begin{array}{l}\text { A14-16. } \\
\text { A } 14-16 . \\
\text { A } 14-16 . \\
\text { A } 16-18 . \\
\text { A } 16-18 .\end{array}$ & $\begin{array}{r}\text { In. }{ }^{3} \\
10.1 \\
10.4 \\
10.3 \\
8.4 \\
8.2\end{array}$ & $\begin{array}{r}\text { In. }{ }^{3} \\
6.1 \\
6.4 \\
6.3 \\
5.1 \\
4.8\end{array}$ & $\begin{array}{r}\text { Inches } \\
2.13 \\
2.15 \\
2.17 \\
2.11 \\
2.08\end{array}$ & $\begin{array}{r}\text { Inches } \\
3.51 \\
3.50 \\
3.52 \\
3.52 \\
3.52\end{array}$ & $\begin{array}{r}0.385 \\
.381 \\
.381 \\
.374 \\
.371\end{array}$ & $\begin{array}{r}\text { In.4 } \\
21.5 \\
22.4 \\
22.3 \\
17.8 \\
17.0\end{array}$ & $\begin{array}{r}\text { In.4 } \\
20.5 \\
21.5 \\
24.5 \\
16.9 \\
16.2\end{array}$ \\
\hline $\begin{array}{l}\text { VI } \\
\text { VII } \\
\text { VIII } \\
\text { IX } \\
\text { X }\end{array}$ & $\begin{array}{l}\text { A } 16-18 \\
\text { C14-16. } \\
\text { C14-16. } \\
\text { C14-16. } \\
\text { B16-16. }\end{array}$ & $\begin{array}{r}8.7 \\
10.5 \\
10.4 \\
10.6 \\
8.7\end{array}$ & $\begin{array}{l}5.1 \\
6.4 \\
6.4 \\
6.5 \\
4.6\end{array}$ & $\begin{array}{l}2.09 \\
2.15 \\
2.20 \\
2.16 \\
1.51\end{array}$ & $\begin{array}{l}\text { 3. } 57 \\
\text { 3. } 51 \\
\text { 3. } 54 \\
\text { 3. } 52 \\
2.84\end{array}$ & $\begin{array}{l}.369 \\
.380 \\
.383 \\
.380 \\
.347\end{array}$ & $\begin{array}{l}18.1 \\
22.5 \\
22.8 \\
23.0 \\
13.2\end{array}$ & $\begin{array}{l}17.4 \\
20.4 \\
20.8 \\
26.3 \\
13.9\end{array}$ \\
\hline 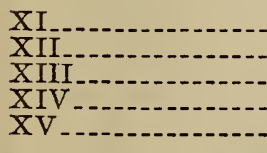 & $\begin{array}{l}\text { B16-16. } \\
\text { B16-16. } \\
\text { A14-16. } \\
\text { A16-18. } \\
\text { B16-16. }\end{array}$ & $\begin{array}{r}8.5 \\
9.2 \\
10.8 \\
8.5 \\
9.0\end{array}$ & $\begin{array}{l}4.5 \\
4.8 \\
6.6 \\
5.0 \\
4.7\end{array}$ & $\begin{array}{l}1.50 \\
1.49 \\
2.17 \\
2.10 \\
1.48\end{array}$ & $\begin{array}{l}2.85 \\
2.88 \\
3.53 \\
3.54 \\
2.86\end{array}$ & $\begin{array}{l}.345 \\
.341 \\
.381 \\
.372 \\
.341\end{array}$ & $\begin{array}{l}12.7 \\
13.7 \\
23.4 \\
17.8 \\
13.4\end{array}$ & $\begin{array}{l}13.4 \\
13.8 \\
23.4 \\
17.1 \\
13.4\end{array}$ \\
\hline $\begin{array}{l}\text { XVI } \\
\text { XVII } \\
\text { XVIII } \\
\text { XIX } \\
\text { XX }\end{array}$ & $\begin{array}{l}\text { A } 14-14 . \\
\text { A } 14-14- \\
\text { A14-14- } \\
\text { A } 12-12 . \\
\text { A12-12. }\end{array}$ & $\begin{array}{l}12.0 \\
11.8 \\
11.6 \\
15.9 \\
16.5\end{array}$ & $\begin{array}{r}8.1 \\
8.1 \\
8.0 \\
10.6 \\
10.4\end{array}$ & $\begin{array}{l}2.30 \\
2.32 \\
2.33 \\
2.22 \\
2.15\end{array}$ & $\begin{array}{l}3.41 \\
3.39 \\
3.38 \\
3.31 \\
3.42\end{array}$ & $\begin{array}{l}.403 \\
.406 \\
.405 \\
.402 \\
.386\end{array}$ & $\begin{array}{l}27.6 \\
27.3 \\
27.1 \\
35.2 \\
35.5\end{array}$ & $\begin{array}{l}27.0 \\
25.4 \\
26.2 \\
33.7 \\
35.9\end{array}$ \\
\hline $\begin{array}{l}\text { XXI } \\
\text { XXII } \\
\text { XXIII } \\
\text { XXIV }\end{array}$ & $\begin{array}{l}\text { A } 12-12 . \\
\text { A } 14-16 . \\
\text { A } 14-16 . \\
\text { A } 14-16 .\end{array}$ & $\begin{array}{l}15.9 \\
11.1 \\
11.1 \\
11.0\end{array}$ & $\begin{array}{r}10.4 \\
6.6 \\
6.6 \\
6.6\end{array}$ & $\begin{array}{l}\text { 2. } 22 \\
2.11 \\
2.11 \\
2.12\end{array}$ & $\begin{array}{l}3.39 \\
3.53 \\
3.55 \\
3.54\end{array}$ & $\begin{array}{l}.396 \\
.374 \\
.373 \\
.375\end{array}$ & $\begin{array}{l}35.4 \\
23.4 \\
23.5 \\
23.4\end{array}$ & $\begin{array}{l}36.1 \\
22.4 \\
22.9 \\
21.8\end{array}$ \\
\hline
\end{tabular}

Figures 18 to 21 show some typical load-strain curves for the four cells of various panels. The curves for Panel III, Figure 18, show the strains in the panel on the second loading, the dashed lines showing the calculated values of the strains are drawn through the set obtained at zero load after loading to the limiting deflection.

From the compressive and tensile strain data the neutral axis could be located at different loads on the assumption that plane sections remain plane. It was found desirable to express the location of the neutral axis in terms of a proportion of the total height of the cell, thus minimizing the effect of irregularities in the heights of the cells. As will appear later, the relation to load of the apparent position of the neutral axis given by the strain data is of value in determining the way in which the specimen begins to fail at mid-span and also in judging whether the various parts of the section are acting integrally. The location of the neutral axis was expressed in terms of a variable defined as follows:

$$
r=\frac{e_{c}}{e_{c}+e_{t}}
$$

where $e_{c}$ and $e_{t}$ are the compressive and tensile strains respectively. This $r$ is the ratio to the total height of the distance from the neutral axis to the top of the cell. Even when plastic deformation has occurred, $r$ continues to represent quite closely. the position of the neutral axis ${ }^{7}$ provided that the upper and lower elements composing the

${ }^{7}$ Bach and Baumann, Elastizität und Festigkeit, 9th ed., p. 266. Eugen Meyer, Berechnung der Durchbiegung von Stäben, deren Material den Hookeschen Gesetz nicht folgt. Zeit. des Verein Deutscher Ingenieure, p. 167, 1908. 
cell act integrally. Values of $r$ are determined very simply by graphical methods and from these values plots of $r$ against load were made

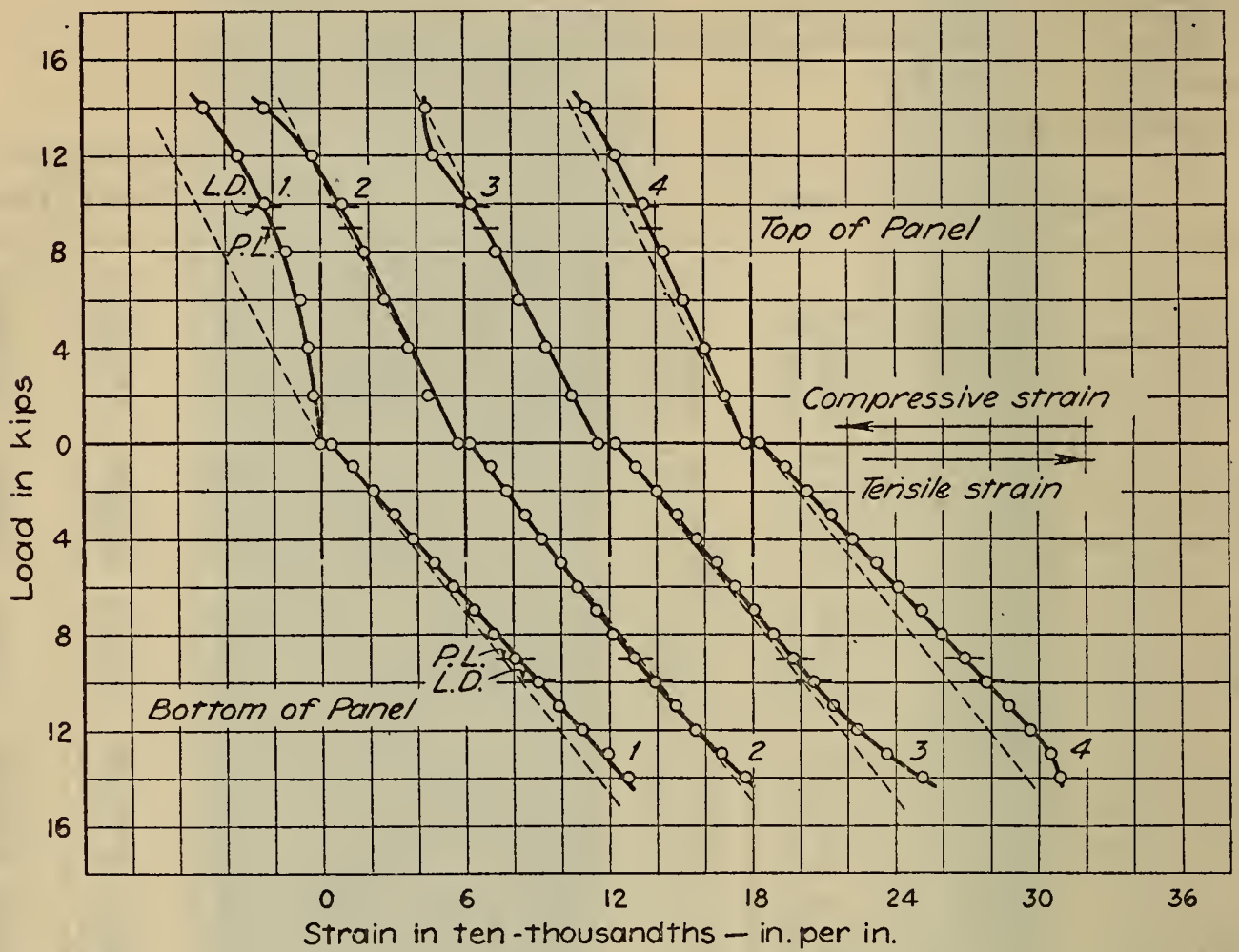

Figure 18.-Load-strain curves for Panel III

for each cell. For a sturdy beam acting according to the usual simple theory, these values of $r$ should be identical with the values of $r_{\text {calc. }}$ given in Table 6 .

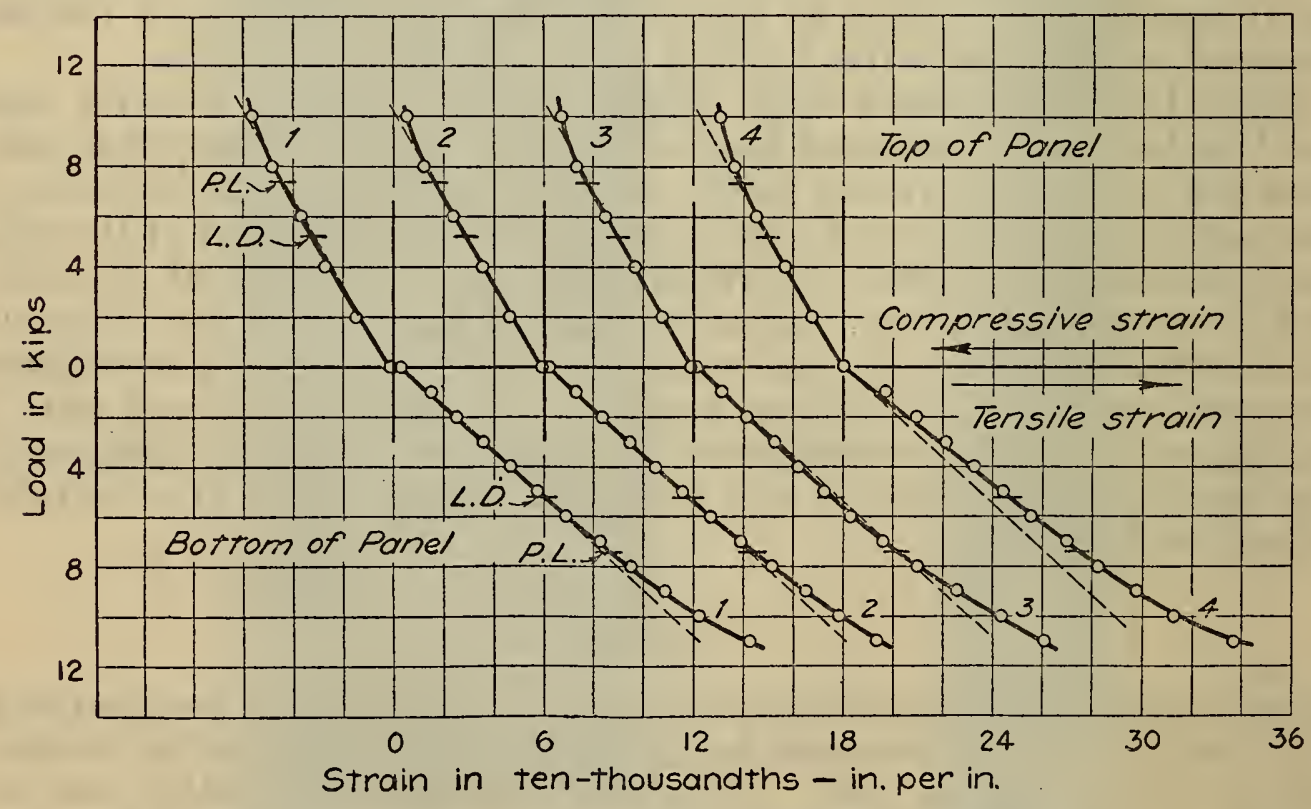

Figure 19.-Load-strain curves for Panel XII

Figures 22 to 24 give characteristic curves showing the values of $r$ at the various loads. The values of $r_{\text {calc }}$ are indicated by the dashed lines. 


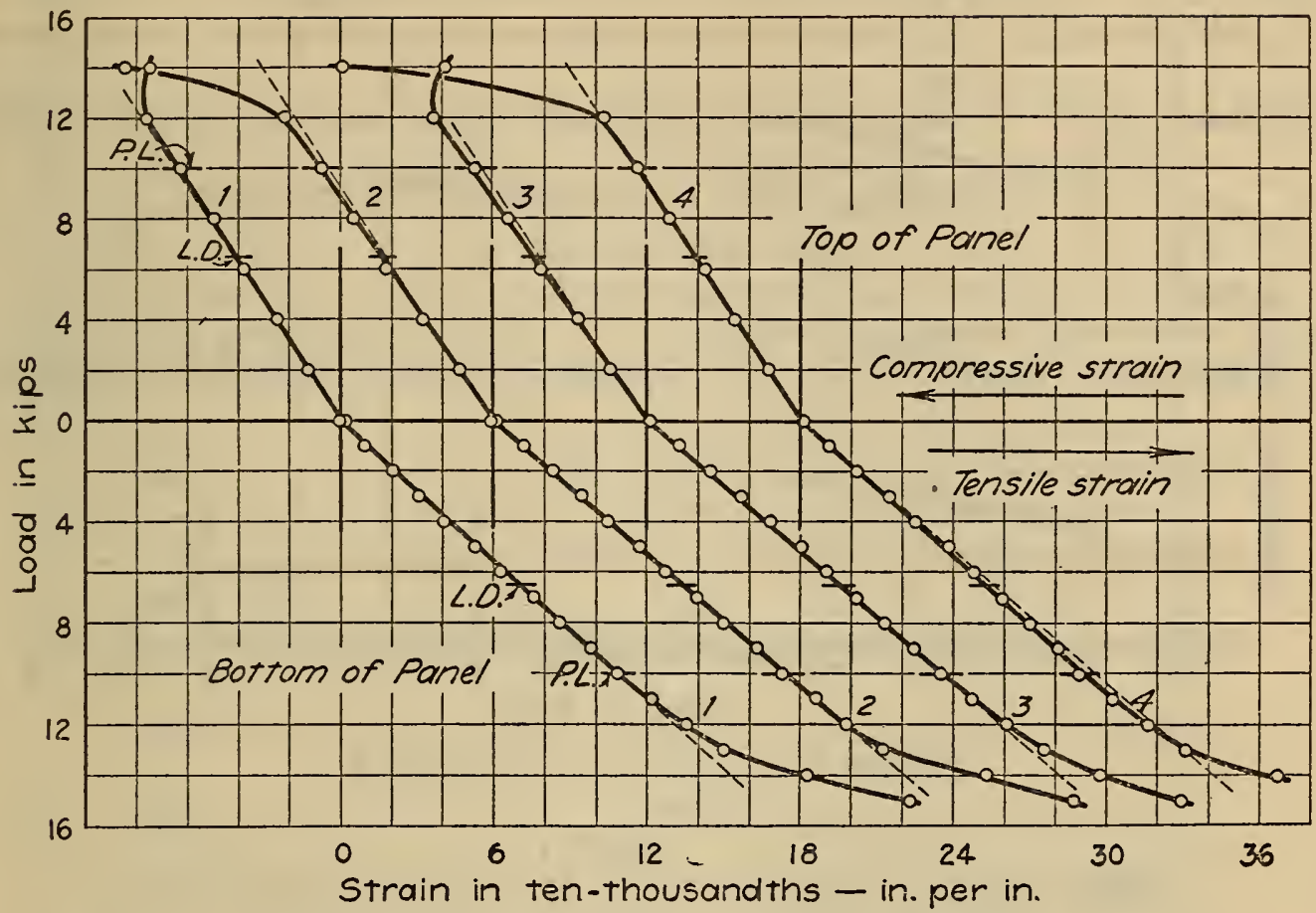

FIgURE 20.-Load-strain curves for Panel XIV

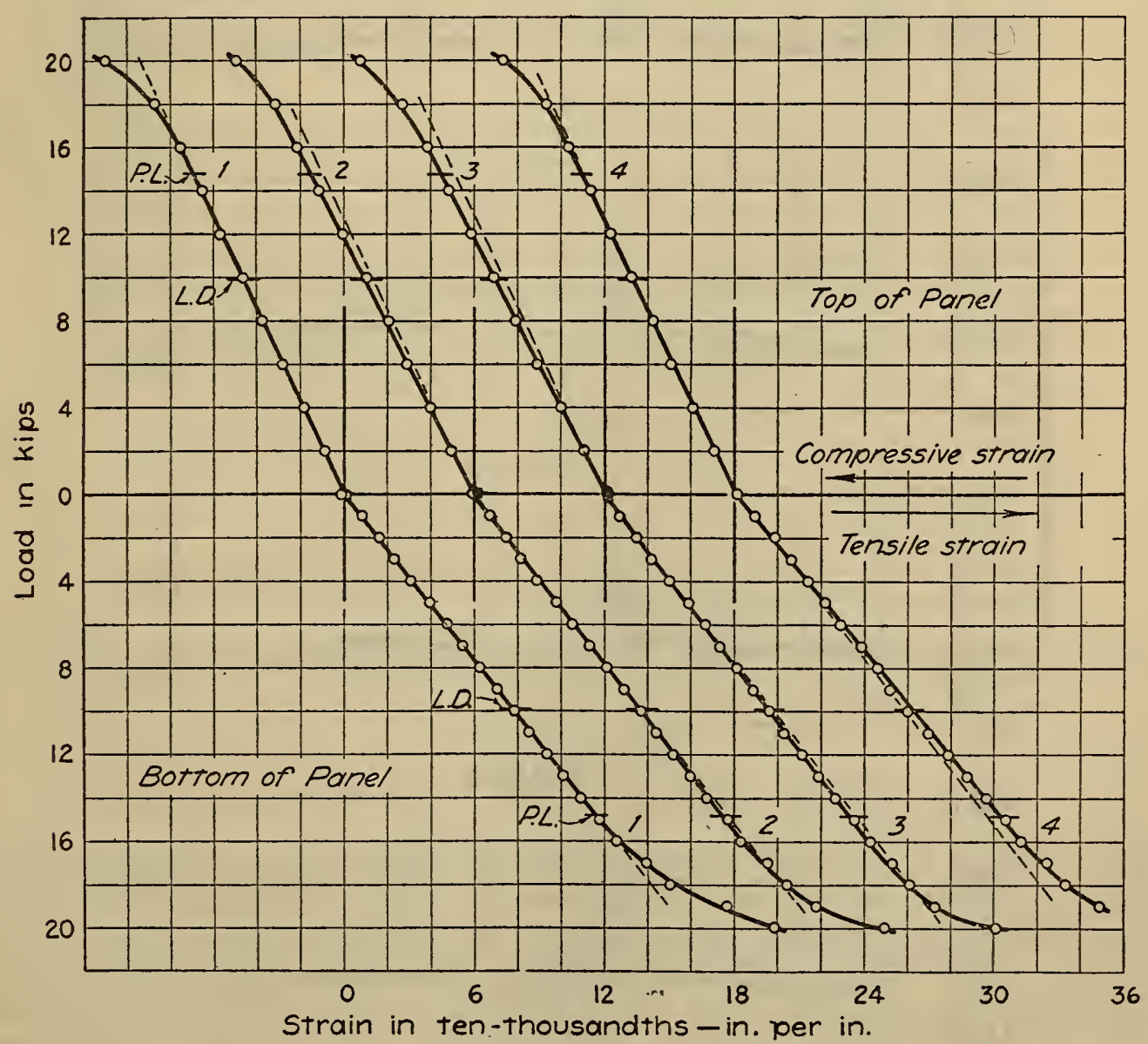

FIgore 21.-Load-strain curves for Panel XXIII 


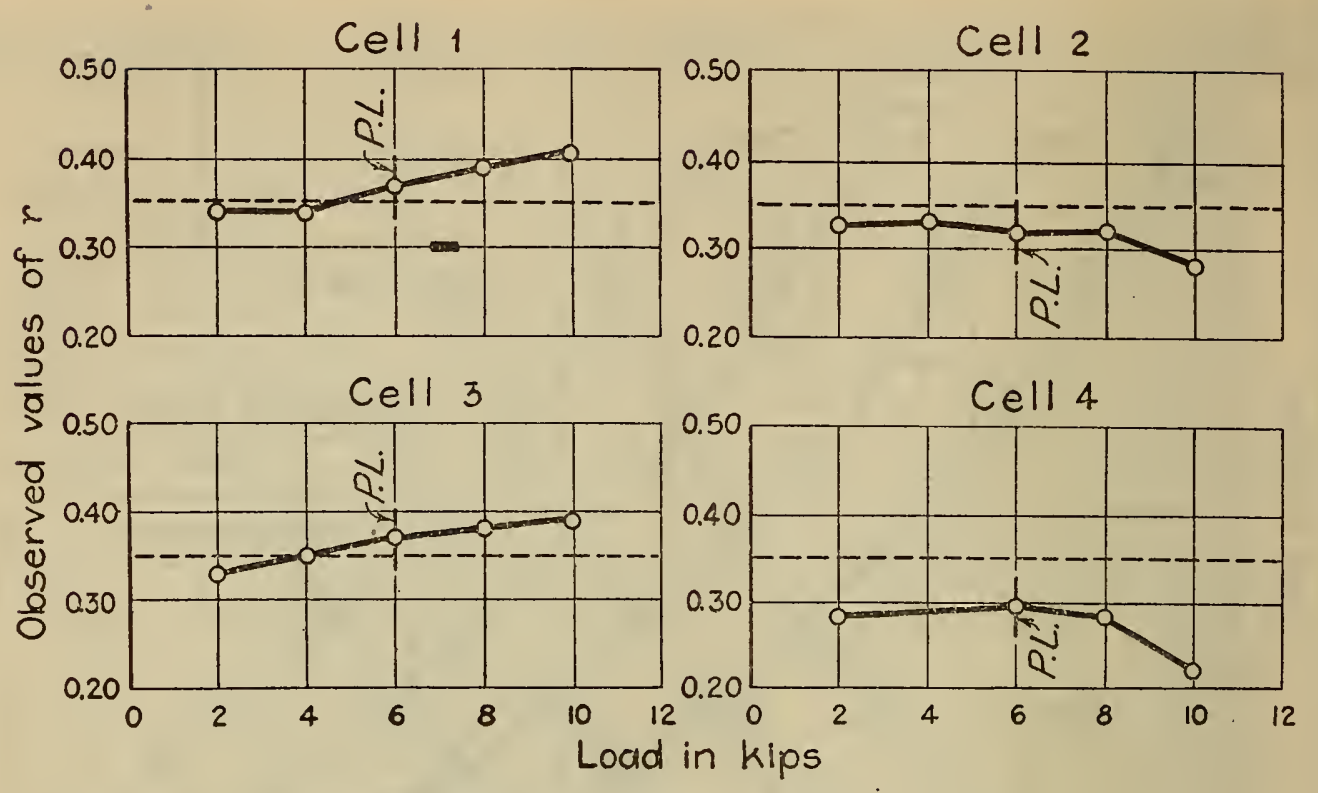

Figure 22.-Values of $r$ for Panel $X$

Cell 1

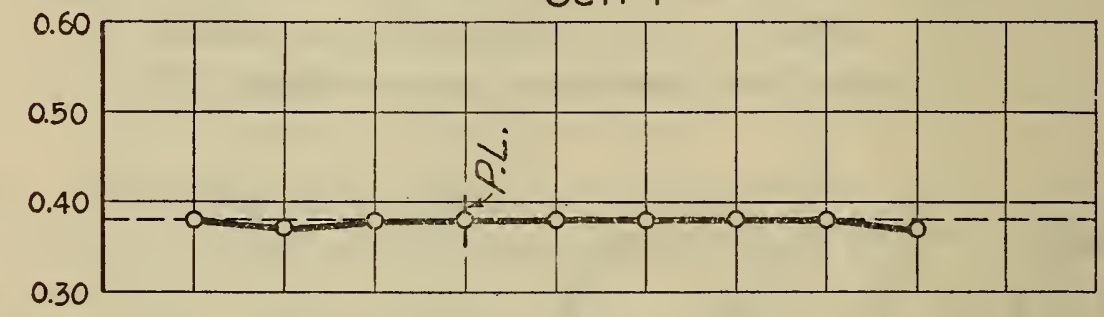

Cell 2

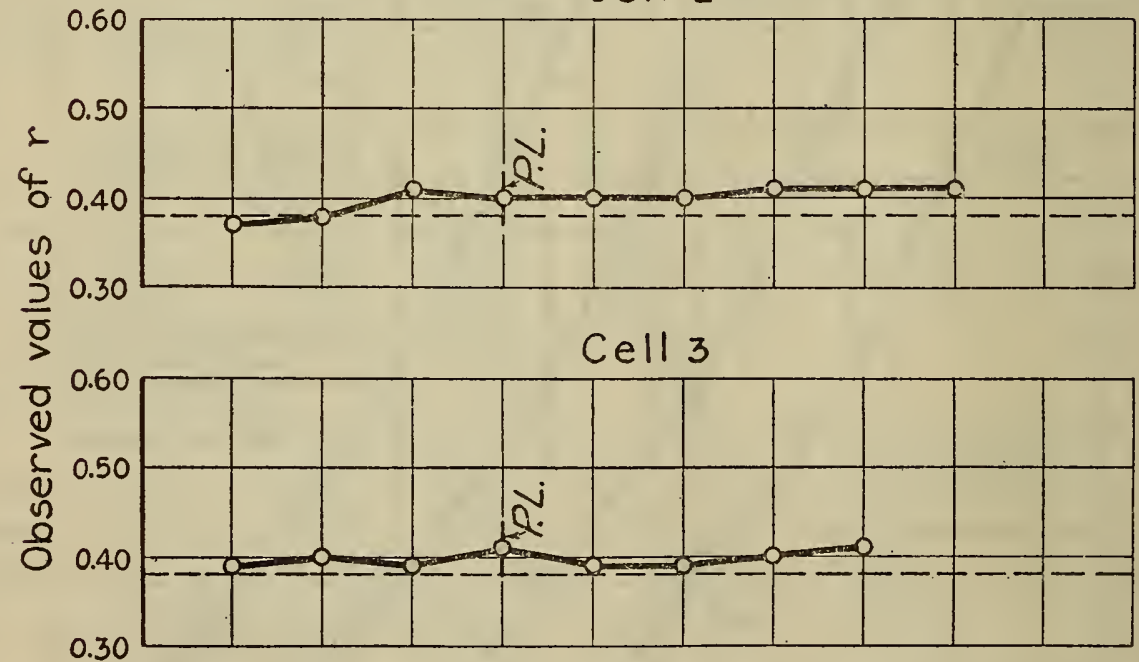

Cell 4

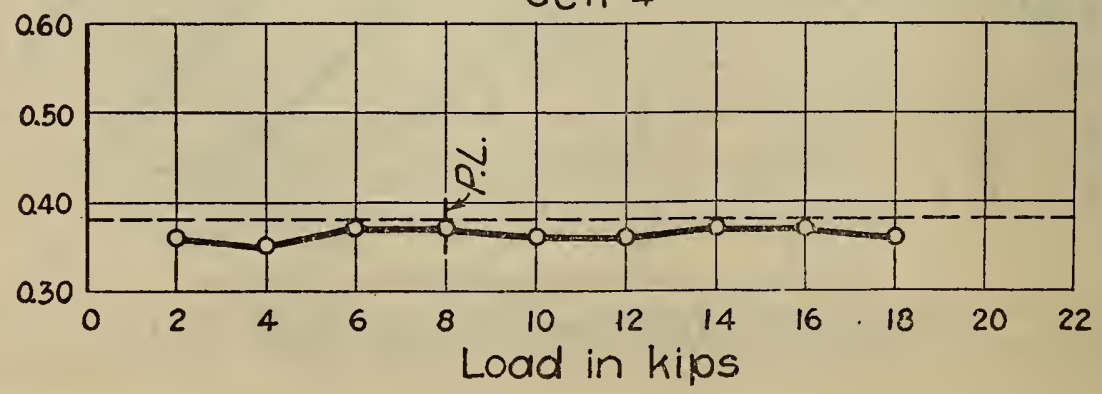

Figure 23.-Values of $r$ for Panel XIII 
Some typical curves showing the reduction in height of the cells over the supports as the load increases are given in Figures 25 to 27.

\section{DISCUSSION OF THE TEST RESULTS OF THE PANELS}

\section{SPECIMENS OF TYPES A AND B}

(a) ELASTIC BEHAVIOR

The close agreement shown in Table 6 between the calculated moment of inertia and that derived from the load-deflection data
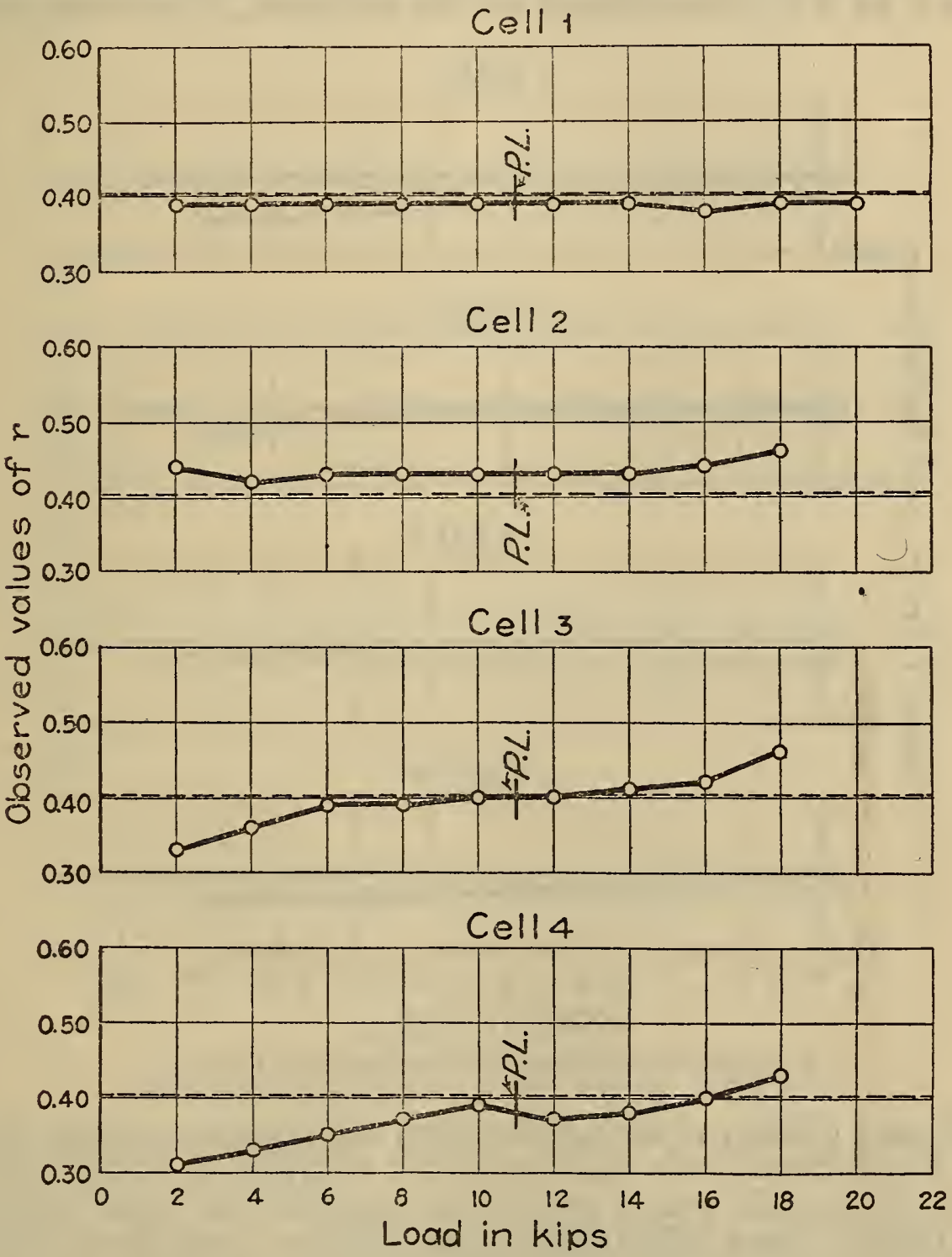

Figure 24.- -Values of $r$ for Panel XVIII

shows that for engineering purposes the specimens of types $A$ and B behaved as purely elastic structures up to the proportional limit. The average ratio of observed to calculated moment of inertia is 98 per cent, the ratios ranging from 93 per cent for panel XVII to 110 per cent for Panel III. For three-quarters of the specimens the ratios were within 4 per cent of the average value. In the load-deflection curves of Figures 12 and 13, the calculated deflection will be seen to 
be close to the observed value, the observed value for all the panels being in general a little greater. The sets in deflection after unloading from the limiting deflection, given in Table 5, were negligible. They were due to readjustment of the specimen near the loads and supports and to local yielding. It is believed that additional applications of load would produce only slight changes in the values of the set. The creep in deflection observed after holding at constant load for one hour at the limiting deflection was negligible, the maximum value being 0.002 inch for Panel XI.

When some of the specimens formed by hand setting of the brake (panels I to XII) were placed on the supports, there were gaps of

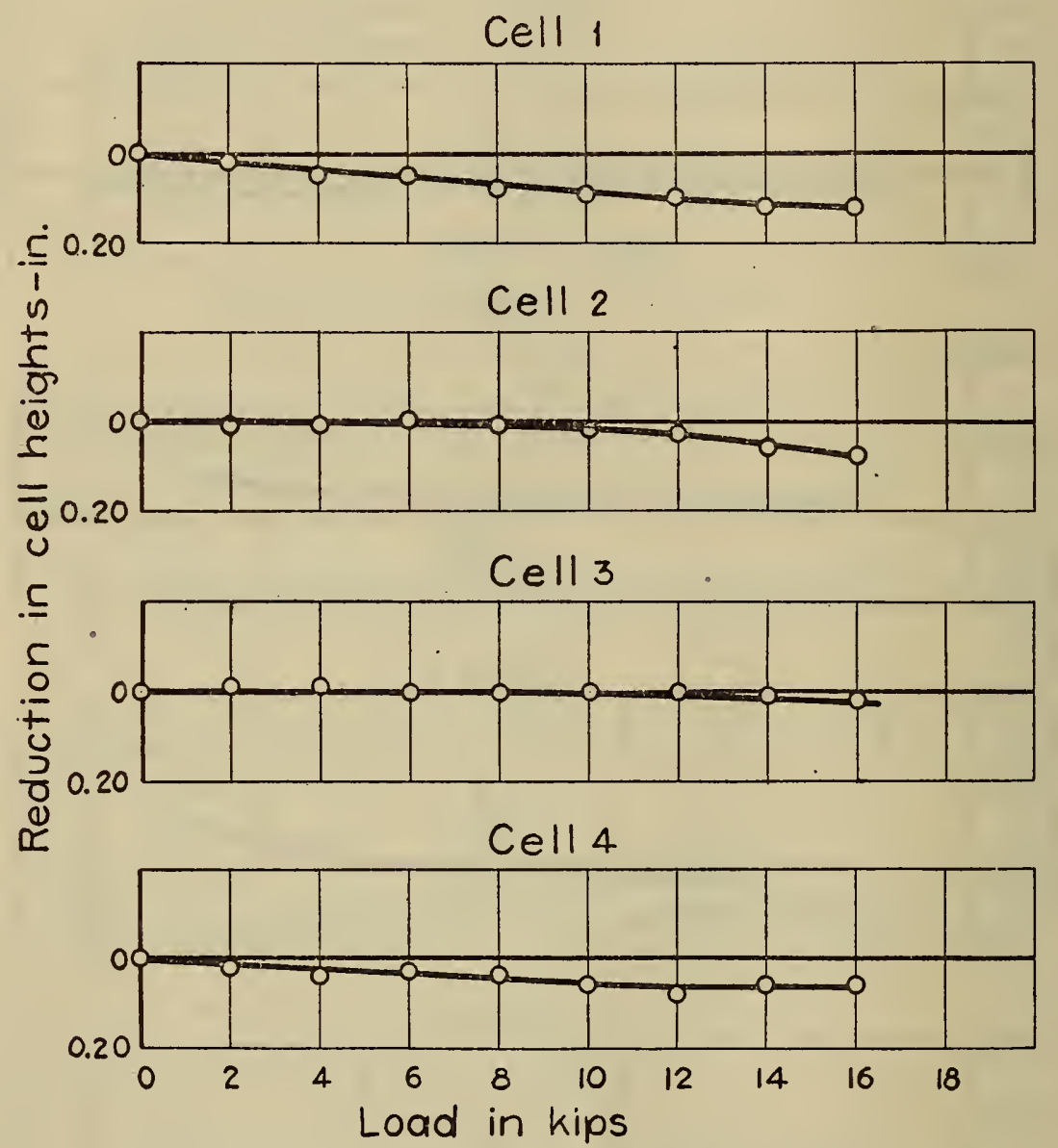

Figdre 25.-Reduction in cell heights, Panel I

as much as a quarter of an inch between cell bottoms and the bearing pads. Furthermore, the loads were not distributed evenly over the cells, since the cell tops were not all quite in the same horizontal plane, though these inequalities were smaller than those observed for the cell bottoms at the supports. When the load was applied the horizontal webs bent, forcing the cell tops into the same plane under the load and tending to close up the gaps over the supports, but even at the limiting deflection the loads and reactions were not evenly distributed over the cells because of the differences in the heights of the cells. Because of this condition, the strain and deflection often increase more rapidly for the first increments of load than for succeeding increments. Examples of this may be seen in the load-deflection curves for Panels IV and X (figs. 12 and 13) and in the load-strain curves for Panel III (fig. 18). 
On the other hand, the die-braked specimens (XII to XXIV) were much more uniform in dimensions and were flatter. For these panels the inequalities of the kind mentioned produced no appreciable effects on the deflections or strains.

The load-strain curves of typical panels given in Figures 18 to 21 show that the observed strain is in no case much greater than that computed by the conventional theory. The sets in the strain readings after loading to the limiting deflection were small, Panel III as a whole showing the largest values of these sets.

For all specimens of types A and B, except Panel III, Table 5 shows that the proportional limit was equal to or higher than the load

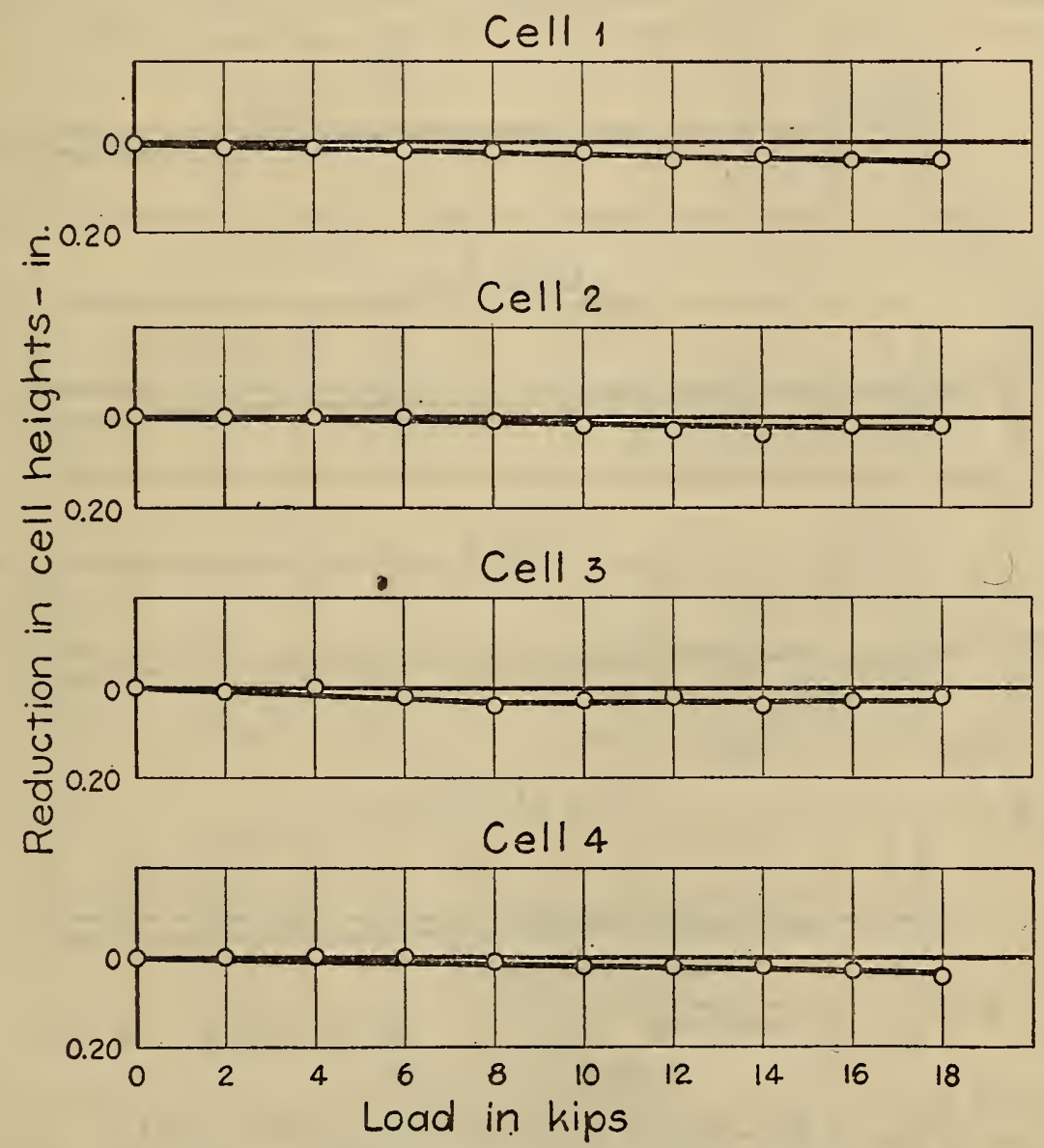

FIgure 26.-Reduction in cell heights, Panel XIII .

at the limiting deflection. Panel III was a product of the earlier manufacturing technique.

Buckling under the loading plates was present in all panels before the limiting deflection was reached and could be observed distinctly looking along the interior of the cell illuminated with a flash light. After removing the limiting deflection load, slight permanent buckles remained in about two-thirds of the panels which were examined for permanent buckles. In one case three of the eight areas of contact of the loading plates with the specimen were buckled, in another case two, and in the remaining five cases only one. It appeared that the uniformity of the die-braked panels resulted in less severe indentation under load and in fewer permanent buckles. For loads below the limiting deflection, the buckling under the loading plates 
is almost entirely elastic. Under repeated loading the presence of slight permanent buckles did not produce any measurable change in the elastic properties.

\section{(b) NEUTRAL AXIS}

The position of the neutral axis as determined by the strain measurements at the middle of the specimens was usually in good agreement with the values calculated from the dimensions. The close agreement of the observed and calculated moments of inertia indicates also that the actual nuetral axis was close to its calculated position. For some cells, however, the observed values of $r$ do not check well

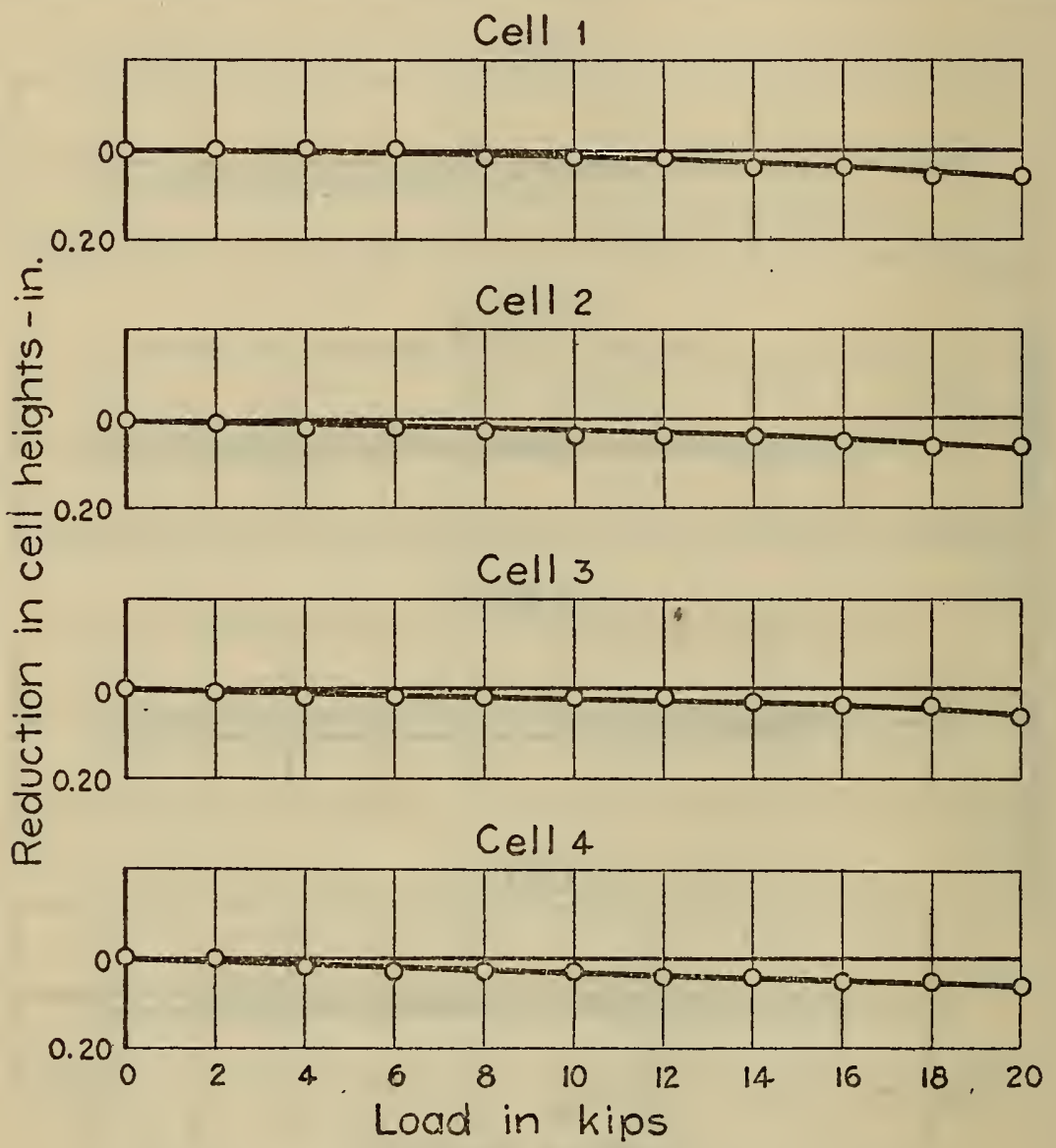

Figure 27.--Reauction in cell heights, Panel XXIV

with the calculated values. An extreme example of this may be seen in Figure 28, showing the values of $r$ for Panel IV. This was due to the top and bottom of the cells not acting integrally in portions of the specimen near the gage lines.

The integral action of the upper and lower elements depends upon shearing forces being transmitted by the welds. When welds fail under load, or if the welding should fail to join portions of the web, there is a lack of integral action between the top and bottom of the panel. What happens then may best be visualized by considering the action of the top and bottom elements when placed together as in the panel, but unconnected by any welding. The bending moment then is distributed between the two elements in proportion to their respective moments of inertia. Since the moment of inertia of the bottom element is much greater than that of the top, most 
of the bending moment will be carried by the lower element. It follows that for a given bending moment on a panel the compressive stress at the top of an unwelded panel is less, while the tensile stress at the bottom is greater than if the panel had been welded. Straingage readings on the upper and lower surfaces of such a panel would indicate the position of the neutral axis to be above that for a welded panel. The values of $r$ observed in such a case would be less than those calculated on the assumption of integral action of the upper and lower elements of the panel.

Actual cases of incomplete integration in the webs are intermediate between the fully welded and the unwelded case described. The values of $r$ in Figure 28 show an extreme effect of this kind. Cells 3 and 4 of Panel XVIII (fig. 24) illustrate the results of poorly inte-

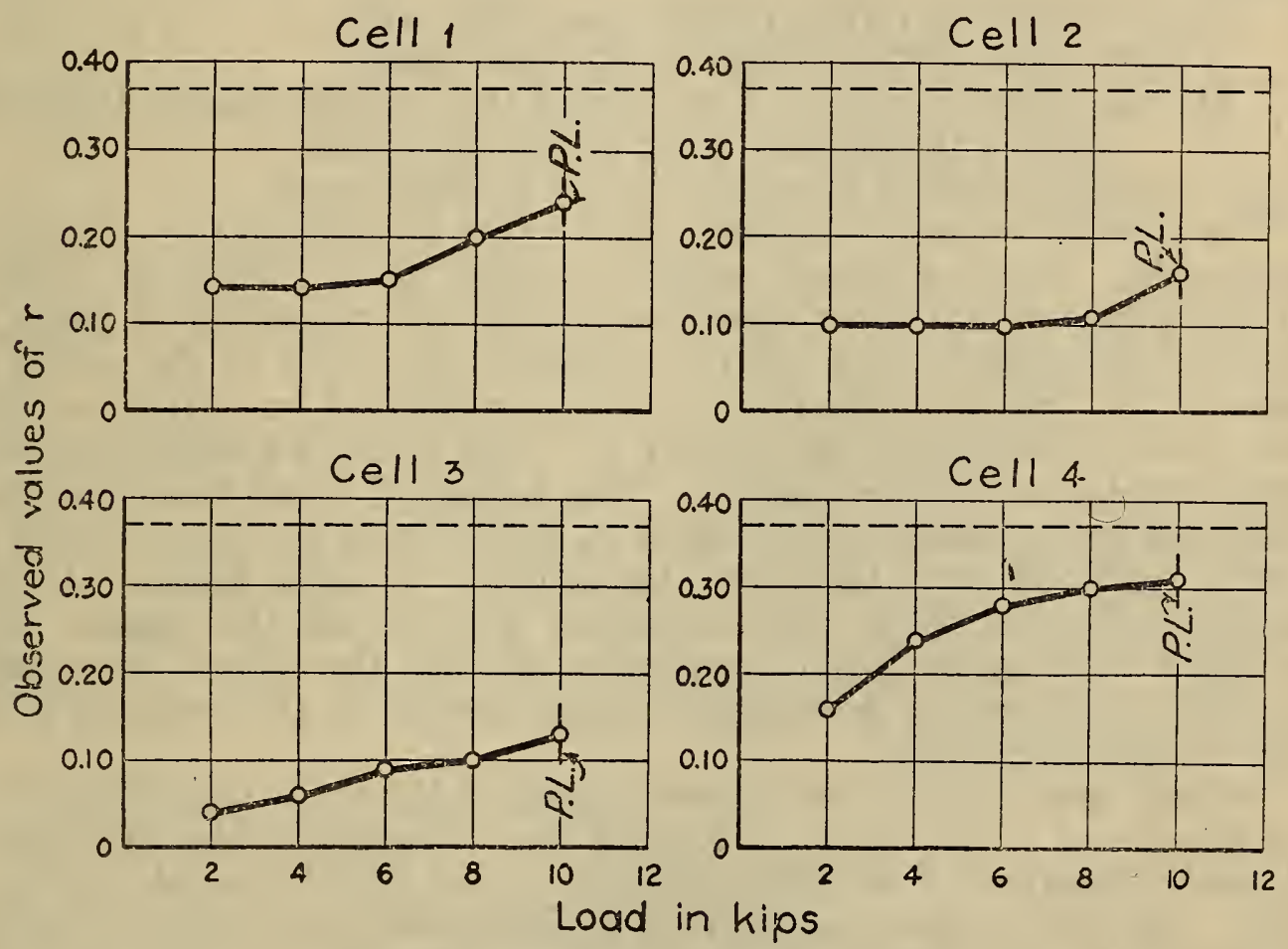

FIgURE 28.- Values of $\mathrm{r}$ for Panel IV

grated portions of the web near mid-span. As the load increased on the panel, the intact welds at the end of the defective portion began to take up the shearing forces that otherwise would have been transmitted by that portion. This tightening-up process brings the value of $r$ nearer the calculated value as the load increases, as can be seen in the curves. The compressive-strain curve for the first cell of Panel III (fig. 18) illustrates the effect of defective integration on the strains. The tensile-strain curve for this cell shows an increase over the calculated value, but the percentage change is not as great as for the compressive strain. In general, it may be said that defective integration in the web reduced the compressive stresses in the upper cells to a greater degree than it increased the tensile stresses in the lower cells. For Panel IV the compressive stresses observed at the proportional limit were markedly lower than the computed values, while the tensile stresses observed were not much greater than the computed values, the maximum value of the observed stress being 
$33.6 \mathrm{kips} / \mathrm{in} .{ }^{2}$ compared with a computed stress of $31.2 \mathrm{kips} / \mathrm{in} .{ }^{2}$. At the limiting deflection the maximum excess of observed over computed tensile stress amounted to 4.3 kips/in. ${ }^{2}$, or 18 per cent, for the handset Panel III, as can be seen in Figure 18 (cell 4). For the more accurately dimensioned panels formed over dies and welded automatically, the maximum excess was $1.9 \mathrm{kips} / \mathrm{in} .^{2}$, or 9 per cent for Panel XIX.

\section{(c) WELDS}

The shearing forces on the welds may be computed from the formula

where

$$
s=\frac{3}{16} \frac{S Q}{I}
$$

$s=$ the shearing force in kips on a single weld,

$S=$ the total vertical shear in kips per panel,

$Q=$ the static moment in in. ${ }^{3}$ about the neutral axis of that portion of the section lying above the welds.

$I=$ the moment of inertia in in. ${ }^{4}$ of a single panel.

The coefficient three-sixteenths inch takes account of the spacing of the welds. For the panels tested, $s$ ranged from $0.032 S$ to $0.036 S$. At the proportional limit, the panels with the exception of those of the A12-12 type gave a minimum factor of safety of the welds in shear of 10 , based on the conservative strength of two kips per weld that was recommended in Section V. The A12-12 specimens had a minimum factor of safety of 5.5. The failure of welds below the proportional limit, which is indicated in some cases by the decrease of $r$ with load, can not, therefore, be ascribed to shear alone. As the neutral axis was below the horizontal web for all the panels, it is probable that under the compressive stresses the sheets composing the web separated by buckling, causing tension in the welds in addition to shearing forces.

Certain specimens showed poor joining of the webs as indicated by the change of $r$ with load, this being true of many of the first group of panels received (I to XII) and also of the A12-12 panels, XIX to XXI. No failure could be ascribed to defective welds alone, although undoubtedly the increased tensile stress produced yielding in the panels at earlier loads. Any significant effects of poor or inadequate welding would be shown by a lowering of the proportional limit.

\section{(d) CELL HEIGHTS AT THE SUPPORTS}

The pressure of the reactions reduced the height of the cells over the supports as shown by Figures 25, 26, and 27. This reduction of the height was shown to be almost entirely elastic up to the limiting deflection load by the absence of appreciable permanent changes in the cell heights. Except for Panel III, the maximum observed permanent reduction, after applying the limiting deflection load, was 0.03 inch for one cell of Panel XXII. Two cells in Panel III decreased 0.05 inch in height, one cell 0.04 inch, and three cells 0.03 inch. This anomalous behavior of Panel III is due apparently to irregularity in sizes of the cells, this panel having been formed on a hand-set brake. The average permanent reduction in cell heights after unloading from the limiting deflection was 0.007 inch. 
The maximum reductions in cell height observed at the limiting deflection were 0.08 inch for one cell of Panel I, 0.07 inch for one cell of Panel III, and 0.05 inch for one cell of Panel XVI. The high values for Panel I and III are due to the irregularity of dimensions characteristic of the panels formed on the hand-set brake. Values for the other panels were all less than 0.05 inch and averaged 0.02 inch. The reduction in cell height for die-braked panels is therefore negligible at the limiting deflection load.

\section{(e) FAILURE OF THE PANELS}

As the load was increased above the proportional limit, buckles appeared in the cell tops between the loads and increased in size and number up to the maximum load. At the same time the indentations in the cell tops under the loading plates increased slowly in depth and in a few panels buckles appeared in the upper portion of the side walls of the cells. Failure in the upper portion of the specimen appeared to take place entirely by buckling, though the A12-12 specimens (see fig. 16) showed strain lines on the cell tops running about $45^{\circ}$ to the axis of the panel, which indicated that the yield point in compression had been reached.

In no cases did any crumpling or buckling start from irregularities of shape or from dents which had occurred in manufacture or shipment. Even in the panels having the thinnest bottom sheets (18 gage), the reinforcing at the ends of these panels inhibited completely any crumpling of the cell bottoms over the supports.

For most of the specimens sharp cracks were heard as the maximum load was approached and occasionally at loads below the proportional limit. It is believed that these sounds were due to the fracturing of welds. Many weld fractures, however, were undoubtedly inaudible.

Departure from elastic behavior in the specimens may be due to the following causes: (1) Yielding of the cell bottoms in tension, (2) buckling of the cell tops in compression, (3) failure of welds, and (4) effect of the concentrated loads.

The first three points will be discussed in the light of the observations at mid-span, 30 inches from the loads.

The stress at which compression failure by buckling began to occur is dependent on the yield point of the material, since the elastic buckling is negligible with respect to the inelastic. For 14 and 16 gage sheet having a yield point of 20 to $25 \mathrm{kips} / \mathrm{in} .{ }^{2}$, inelastic buckling seemed to set in at a stress of around $12 \mathrm{kips} / \mathrm{in} .^{2}$ for specimens of type A. The 14-gage material with a yield point of 41 to $46 \mathrm{kips} / \mathrm{in}^{2}{ }^{2}$ in type $\mathrm{A}$ buckled at a stress of about $22 \mathrm{kips} / \mathrm{in}^{2}{ }^{2}$ For type B, the buckling stress appeared to be a little lower with respect to the yield point, 16-gage material with a yield point of 21 kips/in. ${ }^{2}$ beginning to show marked buckling at stresses of 10 to 12 kips/in. ${ }^{2}$

The dimensions of panels of the A14-16 and A16-18 types were such that simultaneous compression and tension failures occurred at mid-span provided that the observed values of $r$ were in fair agreement with the computed values. The compression failures in the A16-18 panels, once they started, progressed more rapidly, however, than in the heavier top sheets of the A14-16 type. When the observed values of $r$ agree with the computed values, the ratio of compressive to tensile stress in these two types is about 0.60 . When this ratio 
becomes a little greater, as the A14-14 and A12-12 types, for which it is about 0.67 , failure tends to begin by buckling and then develops by combined buckling and yielding in tension.

In the type $\mathrm{B}$ panels the restraint offered to the buckling by the webs caused tensions in the welds which, in conjunction with the shearing forces, were sometimes enough to cause failure of the welds when buckling was well advanced. In Figure 29 is shown a B16-16 specimen in which the top sheet separated from the bottom sheet at a load near the maximum, thus permitting the buckles to spread from one cell top to another across the full width of the panel.

The effects of the welding on the failures have already been discussed.

The effect of the concentration of the loads on the proportional limits of the panels may best be judged by comparing the stresses at mid-span at the proportional limit with the yield point of the bottom sheets given either by the tensile tests or by the load-strain curves. On the average, the proportional limit occurs at a mid-span stress of around 0.7 of the yield point, though some specimens had proportional limits which develop the yield point stresses at the center (V, XXII, and XXIII). A closer examination of the results on this point is of little use, since in many cases materials of widely different yield points were used for the bottom sheets.

The local effects produced by the concentrated loads may be three, as follows: (1) Indentation and buckling of the cell tops under the loading plates; (2) buckling of the web producing weld failures near the loads and consequently increased tensile stress in the cell bottom; and (3) possibly an increase in stress under the concentrated loads considerably above that calculated from the conventional theory. Such stresses have been predicted by Schnadel. ${ }^{8}$ For box girders with a length of 6.3 times the width and loaded at the quarter points, he has calculated the maximum longitudinal stress in the top and bottom plates at the quarter points to be 70 per cent in excess of that at midspan.

The disappearance of buckles under the loading plates on unloading from the limiting deflection and the fact that there was no evidence of reduction in the proportional limit on repeated loading justifies the conclusion that indentation of the cell tops by the concentrated loads is of small importance up to the proportional limit. It would be reasonable to expect, however, that the indentations would lower the compressive resistance of the panel at these points. The effect predicted by Schnadel should be verified by some independent means, but must be accepted as a possibility. In any case, it may be concluded that under uniform loading and on similar spans the panels will behave satisfactorily over a range at least equal to that given by the proportional limit of the present tests.

Had the dimensions of the first 12 specimens been uniform and had the material and welding been likewise more uniform, the results would, undoubtedly, have not shown so much scatter. The tests have shown that the three stages of manufacturing technique have resulted in panels progressively better in strength properties and in uniformity of dimensions.

8 Georg Schnadel, Die mittragende Breite in Kastenträgern und in Doppelboden, Werft-Reederei-Hafen, Mar. 7, 1928, Heft 5, p. 92. 


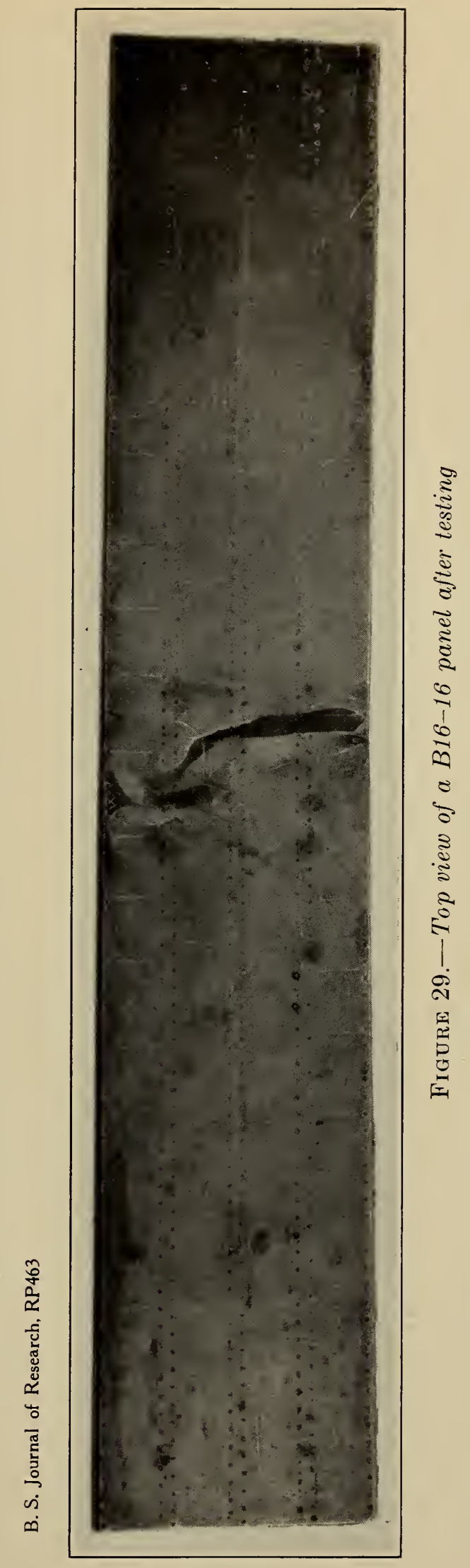




\section{SPECIMENS OF TYPE C}

The agreement between the observed and computed moments of inertia in Table 6 is poor for the specimens of type C. No reason was found for the high moment of inertia observed for Panel IX. The proportional limits (Table 5) were low with respect to the limiting deflection loads and the maximum loads were lower than for any specimens of the A14-16 type. The panels failed from an inherent defect in design, the sheets composing the webs splitting apart at the ends due to combined tension and shear on the welds. The tension on the welds was produced by the panel being supported at the ends only by the projecting top element.

\section{CONCLUSIONS}

The loading tests on sheet steel floor panels having longitudinal stiffening cells and either flat or corrugated top surfaces justify the following conclusions for types $\mathrm{A}$ and $\mathrm{B}$ (fig. 1).

1. The elastic range of the panels was equal to or in some cases in excess of the maximum working range set by the usual deflection requirements (deflection less than one three hundred and sixtieth of the span) in 10-foot floor panels. This elastic range is the fundamental criterion of the usefulness of the panels.

2. The maximum load carried by these panels showed a considerable and satisfactory margin of safety against overloading.

3 . The method in common use for designing beams affords a satisfactory basis for predicting the elastic behavior of these floor sections. The stiffness of the panels calculated from average dimensions was in excellent agreement with that calculated from the deflection. The distribution of longitudinal stress in the die-braked panels can be satisfactorily predicted by the usual methods of design if an allowance of 10 per cent is made to cover the possible irregularities in the distribution of tensile stress.

4. The spot welds used in joining tbe sheets were amply strong in shear, but some may have failed by buckling apart of the two sheets in the web between the welds. These failures, however, had no appreciable effect on the behavior of the panels within the elastic range.

5. The location of the neutral axis is in accord with the calculated location except where imperfect integration by the welds of the top and bottom elements of the section may lead to a displacement. It is therefore desirable that controlled automatic welding be used in the manufacture of such panels.

6 . The thin-walled sections showed a considerable stability against secondary failure, even under concentrated loads.

Panels of type C (fig. 1) showed an inherent defect in design, failure being due to tension on the end welds of the web, there being no provision to strengthen the ends of the webs to withstand these forces.

Washington, June 4, 1932.

$127984-32-4$ 